\title{
Tibouchina (Melastomataceae) do estado do Paraná, Brasil
} Tibouchina (Melastomataceae) from Paraná state, Brazil

\author{
Fabrício Schmitz Meyer ${ }^{1}$, Paulo José Fernandes Guimarães ${ }^{2}$ \& Renato Goldenberg ${ }^{3}$
}

\begin{abstract}
Resumo
As espécies de Tibouchina são herbáceas, arbustivas ou arbóreas, freqüentes nas áreas abertas ou em regeneração, nas diversas formações vegetacionais do estado do Paraná. O gênero pode ser reconhecido pelas flores diplostêmones, com estames dispostos em dois ciclos desiguais, com apêndices do conectivo ventrais, bilobados, ovário súpero revestido por tricomas no ápice, e frutos capsulares com semente cocleadas, com superfície tuberculada. No Paraná, o gênero está representado por 30 espécies, das quais 26 nativas, incluindo duas espécies endêmicas, e outras quatro que ocorrem apenas sob cultivo. Neste trabalho, são apresentadas chave de identificação ilustrada, descrições, comentários taxonômicos, listas de coletores e dados de distribuição geográfica das espécies.
\end{abstract}

Palavras-chave: florística, Melastomeae, taxonomia.

\begin{abstract}
The species of Tibouchina are herbaceous, shrubby or arboreal, and are frequent in open or regenerating areas in vegetation types in the state of Paraná. They can be recognized by the diplostemonous flowers, with two unequal cycles of stamens, these with ventral, bilobed appendages on the connective, by the ovary covered by trichomes at its apex, and by the capsular fruits with cochleate and tuberculate seeds. In Paraná the genus has 30 species, from which 26 are native, including two endemics, and the other four are cultivated. Here we present an illustrated key, descriptions, taxonomic comments, specimen lists and data on the distribution of the species.
\end{abstract}

Key-words: floristics, Melastomeae, taxonomy.

\section{Introdução}

Melastomataceae é constituída por cerca 4.570 espécies amplamente distribuídas nas porções tropicais do planeta (Clausing \& Renner 2001). Tibouchina Aubl. é neotropical e está representado por cerca de 240 (Renner 1993) a 350 espécies (Todzia \& Almeda 1991). O gênero apresenta dois centros de diversidade na América Latina, um nas Regiões Centro-Oeste e Sudeste do Brasil, e o outro, menos expressivo, no noroeste da América do Sul (Guimarães 1997; Peralta 2002). Apresentam porte herbáceo, arbustivo ou arbóreo e são reconhecidas por suas flores 4 ou 5 meras, estames férteis dispostos em dois ciclos desiguais ou pouco desiguais, apêndices bituberculados ventrais, ovário súpero revestido por tricomas no ápice e fruto capsular com sementes cocleadas, diminutamente tuberculadas (Todzia \& Almeda 1991; Wurdack 1962).

As espécies sulinas são mais bem conhecidas que as do restante do Brasil, em razão dos estudos taxonômicos já desenvolvidos para os estados do Rio Grande do Sul (Souza 1986), Santa Catarina (Wurdack 1962), e agora com o Paraná. Ainda assim, existem grupos de espécies bastante problemáticos, em especial as espécies de menor porte, cujas lacínias dos frutos são persistentes, e que pertencem às seções Pseudopterolepis Cogn., Diotanthera (DC.) Cogn. e Simplicicaules Naudin. No tratamento taxonômico aqui apresentado, foram elaboradas chave de identificação ilustrada, descrições, comentários que visam auxiliar na identificação dos táxons e listagem de coleções.

\footnotetext{
'Programa de Pós Graduação em Botânica (UFPR). schmitzmeyer@gmail.com

${ }^{2}$ Instituto de Pesquisas Jardim Botânico do Rio de Janeiro, R. Pacheco Leão 915, 22460-030, Rio de Janeiro, RJ.

${ }^{3}$ Depto. Botânica / SCB / UFPR. C.P. 19031, 81531-970, Curitiba, PR.rgolden@ufpr.br
} 


\section{Materiais e Métodos}

O presente trabalho foi realizado com base na análise de 927 coleções depositadas nos herbários EFC, FUEL, HBR, HUEM, HUPG, MBM, R, RB, SPe UPCB (siglas segundo Holmgren \& Holmgren 2009). Foram consultadas obras clássicas que tratam sobre o gênero (Cogniaux 1883-1885; 1891), também os estudos taxonômicos de floras regionais de Santa Catarina (Wurdack 1962), do Rio Grande do Sul (Souza 1986), de São Paulo (Guimarães \& Martins 1997; Guimarães \& Oliveira 2009; Oliveira 2001), além da revisão taxonômica da seção Pleroma (D.Don) Cogn. (Guimarães 1997). Para cada espécie, apenas as coletas provenientes do Paraná foram relacionadas como "material selecionado", a partir das quais foram baseadas as descrições. Optou-se citar apenas uma coleta por município, preferencialmente o registro mais recente. Além das espécies nativas foram incluídas no estudo as cultivadas, estando estas sinalizadas com um asterisco na chave de identificação. Táxons infra-genéricos (seções) e infraespecíficos (variedades) não foram considerados neste trabalho, pois não possuem uma delimitação clara (Souza 1986; Guimarães 1997). Com relação à morfologia, o indumento foi descrito com base em Hickey \& King (2000). A distribuição geográfica das espécies foi descrita com base nos espécimes analisados, em bibliografia e coletas.

Descrições mais detalhadas sobre o relevo, clima e vegetação do Paraná podem ser encontradas em Maack (1968), Roderjan et al. (1993), Goldenberg (2004) e Camargo \& Goldenberg (2007).

\section{Tratamento Taxonômico}

Tibouchina Aubl., Hist. pl. Guiane 1: 445, t. 177. 1775.

Árvores, arvoretas, arbustos ou ervas, freqüentemente com xilopódio. Ramos cilíndricos, subcilíndricos, quadrangulares, sem alas, diminutamente alados ou com alas bastante desenvolvidas, com ou sem indumento. Folhas opostas, raramente verticiladas, pecioladas ou não; lâmina desde elípticas, lanceoladas, ovais, oblanceoladas a cordiformes, margem lisa ou crenulada, glabra ou revestida por tricomas em ambas as faces; nervuras 3-9, acródromas, basais, suprabasais ou confluentes. Flores solitárias ou cimeiras de dicásios dispostas em inflorescências tirsóides, 7-21 flores, ou cimeiras menos ramificadas, com 3-9 flores; brácteas ou bractéolas 2-6, geralmente caducas no botão, às vezes persistentes por longo período na flor, de formato variado, desde glabras a indumentadas externamente. Flores pentâmeras ou tetrâmeras, menos freqüentemente hexâmeras ou octâmeras; hipanto tubuloso a campanulado, indumento estrigoso, seríceo, setoso, escabroso, lanoso ou dendrítico, tricomas simples multisseriados, complexos (ramificados) ou glandulares, freqüentemente apresentando mais de um tipo; lacínias do cálice caducas ou persitentes quando em fruto, ápice agudo, cuspidado, subulado ou obtuso, glabras ou com indumento semelhante ao do hipanto, distribuídos externamente por toda a extensão da lacínia ou apenas na porção central; pétalas com coloração permanente ou mutável, desde os variados tons do rosa, roxo, purpúreo, branco ou vináceo; estames 10 ou 8 , desiguais ou pouco desiguais; filetes com indumento variado ou glabros; conectivos bastante ou pouco prolongados, apêndices ventrais bilobados, glabros ou indumentados; anteras com ápice subulado ou truncado; ovário com ápice revestido por indumento variado; estilete com indumento variado ou glabro. Fruto capsular, sementes numerosas, cocleadas, diminutamente tuberculadas.

Tibouchina está representado no Paraná por 30 espécies, das quais 26 são nativas e quatro cultivadas. Destas, cinco espécies ocorrem também fora do Brasil (T. clinopodifolia, T. debilis, $T$. gracilis, T. guimaraensis e T. martialis); as 25 restantes são exclusivamente brasileiras, cinco delas endêmicas da Região Sul ( $T$. dusenii, $T$. goldenbergii, T. kleinii, T. pilosa e T. saxicola), sendo $T$. saxicola e $T$. goldenbergii endêmicas do Paraná. Segundo critérios da UICN (2001), seis espécies de Tibouchina estão ameaçadas de extinção. Tibouchina goldenbergii, T. riedeliana e T. saxicola estão em perigo crítico, pois têm distribuição muito restrita, com populações muito pequenas (UICN 2001). Tibouchina dusenii, T. herincquiana e T. kleinii enquadram-se na categoria "vulnerável", visto que destas ocorrem populações naturais pequenas, restritas a ecossistemas ameaçados. As demais espécies aparentemente não estão ameaçadas de extinção.

Os exemplares nativos ocupam todas as formações vegetacionais do estado, mas a maior porção das espécies está associada à vegetação de floresta ombrófila densa (floresta atlântica) e estepe (campos). Um número menor de espécies ocorre em savanas (cerrados), floresta ombrófila mista (floresta com Araucária) e floresta estacional semi-decídual (floresta da Bacia do Rio Paraná). 


\section{Chave de identificação para as espécies de Tibouchina no estado do Paraná}

1. Flores tetrâmeras, raramente mescladas com flores pentâmeras dispostas no centro do dicásio.

2. Pétalas brancas; anteras com ápice truncado (Fig. 1c)

18. T. hospita

2'. Pétalas purpúreas, róseas ou roxas; anteras com ápice subulado (Fig. 1a).

3. Folhas com 3 nervuras basais; lâmina lanceolada, 0,2-0,8 cm larg. (Fig. 1e) .... 26. T. saxicola

3'. Folhas com 5-7 nervuras com os pares laterais confluentes; lâmina oval a elíptica, 1,1-3,5 cm larg. (Fig. 1d) 2. T. cerastifolia

1'. Flores exclusivamente pentâmeras.

4. Ervas ou subarbustos, frequentemente com xilopódio subterrâneo; cálice com lacínias persistentes nos frutos (Fig. 1f).

5. Anteras com ápice truncado (Fig. 1b)

5. T. clinopodifolia

5. Anteras com ápice subulado (Fig. 1a).

6. Face abaxial das folhas, ramos e hipanto com indumento lanoso, com aspecto aveludado (Fig. 1h) 14. T. guimaraensis

6'. Face abaxial das folhas, ramos e hipanto glabros, seríceos, estrigosos, escabrosos, setosos, setulosos, pubérulos, tomentosos, vilosos, hirsutos ou glandulares, sem aspecto aveludado.

7. Inflorescência congesta; hipanto estrigoso a seríceo, tricomas adpressos (Fig. 1k) 12. T. gracilis

7'. Inflorescência laxa; hipanto revestido por indumento setoso, tricomas em posição inclinada (Fig. 1j).

8. Folhas seríceas em ambas as faces

16. T. herincquiana

8'. Folhas com a face adaxial glabra ou estrigosa, face abaxial hirsuta ou setosa

6. T. debilis

4'. Arbustos ou árvores; cálice com lacínias caducas nos frutos (Fig. 1g).

9. Pétalas de coloração mutável, inicialmente brancas, posteriormente róseas a purpúreas.

10. Folhas com 5 nervuras (Fig. 11); estilete esparsa a moderadamente seríceo na base (Fig. $1 \mathrm{~m})$...... 22. T. pulchra

10'. Folhas com 3 nervuras (Fig. 1n); estilete glabro (Fig. 1o).

27. T. sellowiana

9'. Pétalas de coloração permanente, em cores variadas, desde brancas, vinosas, roxas, róseas a purpúreas, frequentemente apenas com porção da unha de coloração diferenciada.

11. Pétalas brancas 8. T. dusenii

11'. Pétalas vinosas, roxas, róseas ou purpúreas.

12. Apêndice do conectivo esparsa a densamente revestido por tricomas glandulares (Figs. 1p-s).

13. Folhas ovais, com base cordada; 7 ou 9 nervuras (Fig. 1t) .... 17. T. heteromalla*

13'. Folhas elíptico-lanceoladas ou elípticas, com base aguda ou obtusa, menos frequentemente acuneada; 3 ou 5 nervuras.

14. Hipanto seríceo ou setoso (Fig. 1u)

9. T. fothergillae*

14'. Hipanto estrigoso-dendrítico (Fig. 1v)

1. T. candolleana*

12'. Apêndice do conectivo glabro.

15. Ramos com alas conspícuas (Fig. 1x); face adaxial da folha com tricomas de base pustulada mesclados com tricomas de base simples; face abaxial dendríticopubescentes (Fig. 2a)

13. T. granulosa*

15'. Ramos sem alas, ou com alas diminutas (Fig. 1w); face adaxial da folha glabra ou com indumento variado, sem tricomas com base pustulada; face abaxial com indumento variado, sem tricomas dendríticos.

16. Brácteas persistentes por longo período na flor, localizadas na base do hipanto (Fig. 2b)

15. T. hatschbachii

16'. Brácteas ou bractéolas precocemente caducas.

17. Folhas discolores; face adaxial com dois estratos de tricomas, ao menos um, geralmente o menor, com tricomas glandulares (Fig. 2c) 
17. Folhas concolores; face adaxial com apenas um estrato de tricomas, este desprovido de tricomas glandulares.

18. Folhas com base cordada ou suavemente cordada (Figs. 2d-g).

19. Hipanto revestido por tricomas exclusivamente não glandulares; ocorrência em formações pioneiras de influência marinha e na floresta ombrófila densa, na formação de terras baixas e submontana.

20. Conectivo dos estames antissépalos 2,5-4 mm compr. 30. T. urvilleana

20'. Conectivo dos estames antissépalos 0,5-1 mm compr. 4. T. clavata

19'. Hipanto revestido, ao menos em parte, por tricomas glandulares; ocorrência em vegetação de estepe gramíneo-lenhosa, savana e floresta ombrófila mista.

21. Pecíolo ausente ou muito curto (Fig. 2e), ca. $1 \mathrm{~mm}$ compr.

29. T. ursina

21'. Pecíolo 7-20 mm compr.

19. T. kleinii

18'. Folhas com base obtusa ou aguda.

22. Face adaxial da folha glabra (Fig. 2j) ou, se estrigosa, tricomas dispostos em faixas longitudinais nos espaços entre as nervuras (Fig. 2i)

22'. Face adaxial da folha com indumento variado, tricomas distribuídos por toda a superfície da lâmina. 23. Hipanto moderada a densamente seríceo.

24. Face adaxial da folha serícea (Fig. 2m)

30. T. urvilleana

24'. Face adaxial da folha estrigosa.

25. Folhas com 7 nervuras (Fig. 21)

11. T. goldenbergii

25'. Folhas com 5 nervuras (Fig. 2k).

26. Ramos não decorticantes; ocorrência em vegetação pioneira de influência marinha e na floresta ombrófila densa, nas formações de terras baixas e submontana .... 23. T. regnellii

26'. Ramos decorticantes; ocorrência em estepe gramíneo-lenhosa ..... 25. T. riedeliana

23'. Hipanto esparsa, moderada ou densamente estrigoso, setoso ou escabroso.

27. Brácteas ou bractéolas com 10-19,5 mm compr.

28. Bractéolas ovais ou elípticas; face adaxial da folha com tricomas de maior dimensão dispostos sobre a nervura central e próximos à base, com 1,5-2 mm compr. (Fig. 2n) 21. T. pilosa

28'. Brácteas ou bractéolas orbiculares; face adaxial da folha desprovida de tricomas de maiores dimensões sobre a nervura central, se presentes menores ou do mesmo tamanho que os da superfície. 24. T. reitzii

27'. Brácteas ou bractéolas com 3,4-8,7 mm compr.

29. Estilete pubérulo, tricomas até $0,2 \mathrm{~mm}$ compr. 19. T. kleinii

29'. Estilete glabro ou seríceo, tricomas 1,3-1,7 mm compr.

30. Estames com filetes vilosos, com tricomas maiores que $1 \mathrm{~mm}$ compr. (Fig. 1a). 31. Lâmina 5-6,2 ×2,4-3 cm; geralmente com folhas verticiladas (Fig. 20 ), às vezes opostas 10. T. frigidula 31'. Lâmina 1,8-3,2×0,7-1,4 cm; folhas sempre opostas (Fig. 2p) 20. T. martialis

30'. Estames com filetes glabros ou glanduloso-setulosos, neste caso com tricomas ca. $0,4 \mathrm{~mm}$ compr. 28. T. trichopoda

1. Tibouchina candolleana (Mart. ex DC.) Cogn. in Mart. \& Eichler, Fl. bras. 14(3): 339. 1885.

Fig. 1p, v

Iconografia: Guimarães \& Oliveira (2009, prancha 15 , fig. d-f)

Arbusto 3-5 m alt. Ramos jovens quadrangulares, não decorticantes, esparsa a moderadamente estrigosos, frequentemente tricomas dendríticos.
Pecíolo 50-70 mm compr.; lâmina 4,8-8,8×1,6-2,8 cm, elíptica, ápice e base agudos, margem lisa, face adaxial moderadamente estrigosa, tricomas ca. $0,5 \mathrm{~mm}$ compr., distribuídos entre as nervuras, frequentemente dendríticos, face abaxial esparsamente estrigosa, tricomas ca. 0,5 mm compr.; nervuras 3, suprabasais. Cimeira de dicásios ou inflorescência tirsóide, 7-21 flores; bractéolas 2, ca. 7,1 ×1,6 mm, oblongas ou 


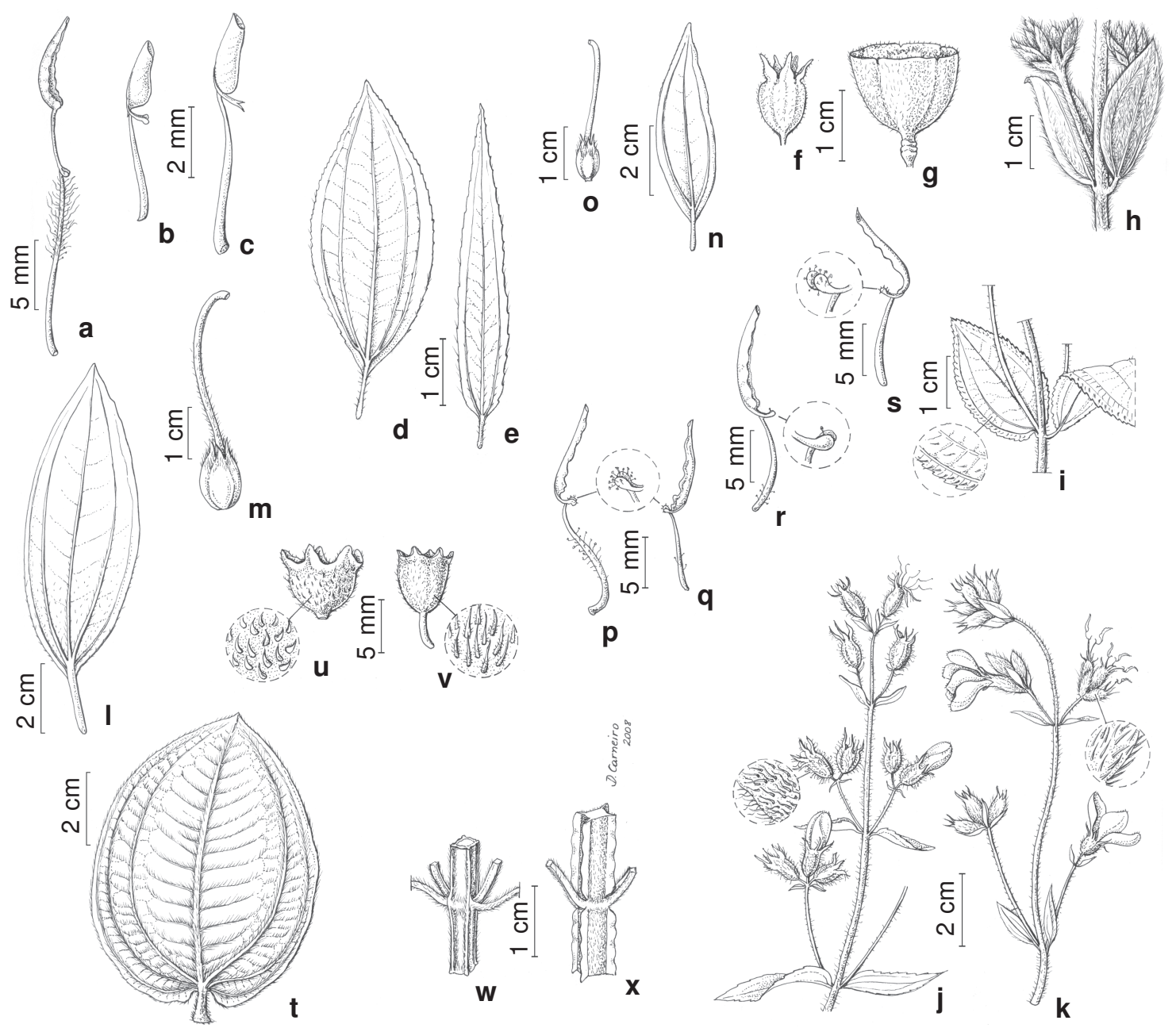

Figura 1 - Detalhes morfológicos de espécies de Tibouchina no Paraná-a-c. estames antissépalos - a. T. martialis (Landrum 4051); b. T. clinopodifolia (Britez 1172); c. T. hospita (Hatschbach 1742). d-e. lâminas e disposição das nervuras (face abaxial) - d. T. cerastifolia (Saldanha 2); e. T. saxicola (Meyer 322). f-g. frutos-f.lacínias do cálice persistentes em T. debilis (Cervi 2916); g. lacínias do cálice caducas em T. pulchra (Aguiar s.n., HUEM 963). h. indumento sob os ramos, folhas, eixo da inflorescência e hipanto em T. guimaraensis (Barbosa 101). i. folha, com detalhe dos tricomas na margem da face adaxial em Tibouchina debilis (Hatschbach 21216).j-k. inflorescência e detalhe do indumento do hipanto-j. T. debilis (Cervi 2916); k. T. gracilis (Hatschbach 40236). 1. lâmina e disposição das nervuras (face abaxial) em T. pulchra (Aguiar s.n., HUEM 963). m. gineceu em T. pulchra (Aguiar s.n., HUEM 963). n. folha, mostrando a disposição das nervuras (face abaxial) em T. sellowiana (Kummrow 2605). o. gineceu em T. sellowiana (Kummrow 2605). p-s. estames antissépalos e detalhe dos apêndices do conectivo com tricomas glandulares - p. T. candolleana (Neto 62); q. T. heteromalla (Gatti 138); r. T. fothergillae (Paula 1); s. T. fothergillae (Cordeiro 1172). t. lâmina e disposição das nervuras (face abaxial) em T. heteromalla (Duarte 56). u-v. hipanto, com detalhe do indumento - u. T. fothergillae (Cordeiro 1172); v. T. candolleana (Neto 62). w-x. forma dos ramos-w. T. urvilleana (Silva 287); x. T. granulosa (Laroca 51).

Figure 1 - Morphological details of Tibouchina species in Paraná - a-c. antisepalous stamens - a. T. martialis (Landrum 4051); b. T. clinopodifolia (Britez 1172); c. T. hospita (Hatschbach 1742). d-e. leaf blades and venation (abaxial view) - d. T. cerastifolia (Saldanha 2); e. T. saxicola (Meyer 322). f-g. fruits - f. with persistent calyx lobes in T. debilis (Cervi 2916); g. with deciduous calyx lobes in T. pulchra (Aguiar s.n., HUEM 963). h. indument on the branches, leaves, inflorescence axis and hypanthium in T. guimaraensis (Barbosa 101). i. leaf with trichomes on the adaxial margin of the blade in T. debilis (Hatschbach 21216). j-k. inflorescence and detail of the indument on the hypanthium-j. T. debilis (Cervi 2916); k. T. gracilis (Hatschbach 40236). 1. blade and venation (abaxial view) in T. pulchra (Aguiar s.n., HUEM 963). m. gynoecium in T. pulchra (Aguiar s.n., HUEM 963). n. leave showing the disposition of ribs (abaxial view) in T. sellowiana (Kummrow 2605). o. gynoecium in T. sellowiana (Kummrow 2605). p-s. antisepalous stamens and detail of the connective appendages with glandular trichomes - p. T. candolleana (Neto 62); q. T. heteromalla (Gatti 138); r. T. fothergillae (Paula 1); s. T. fothergillae (Cordeiro 1172). t. blade and venation (abaxial view) in T. heteromalla (Duarte 56). u-v. hypanthium, with details of the trichomes - u. T. fothergillae (Cordeiro 1172); v. T. candolleana (Neto 62). w-x. branch shape - w. T. urvilleana (Silva 287); x. T. granulosa (Laroca 51). 

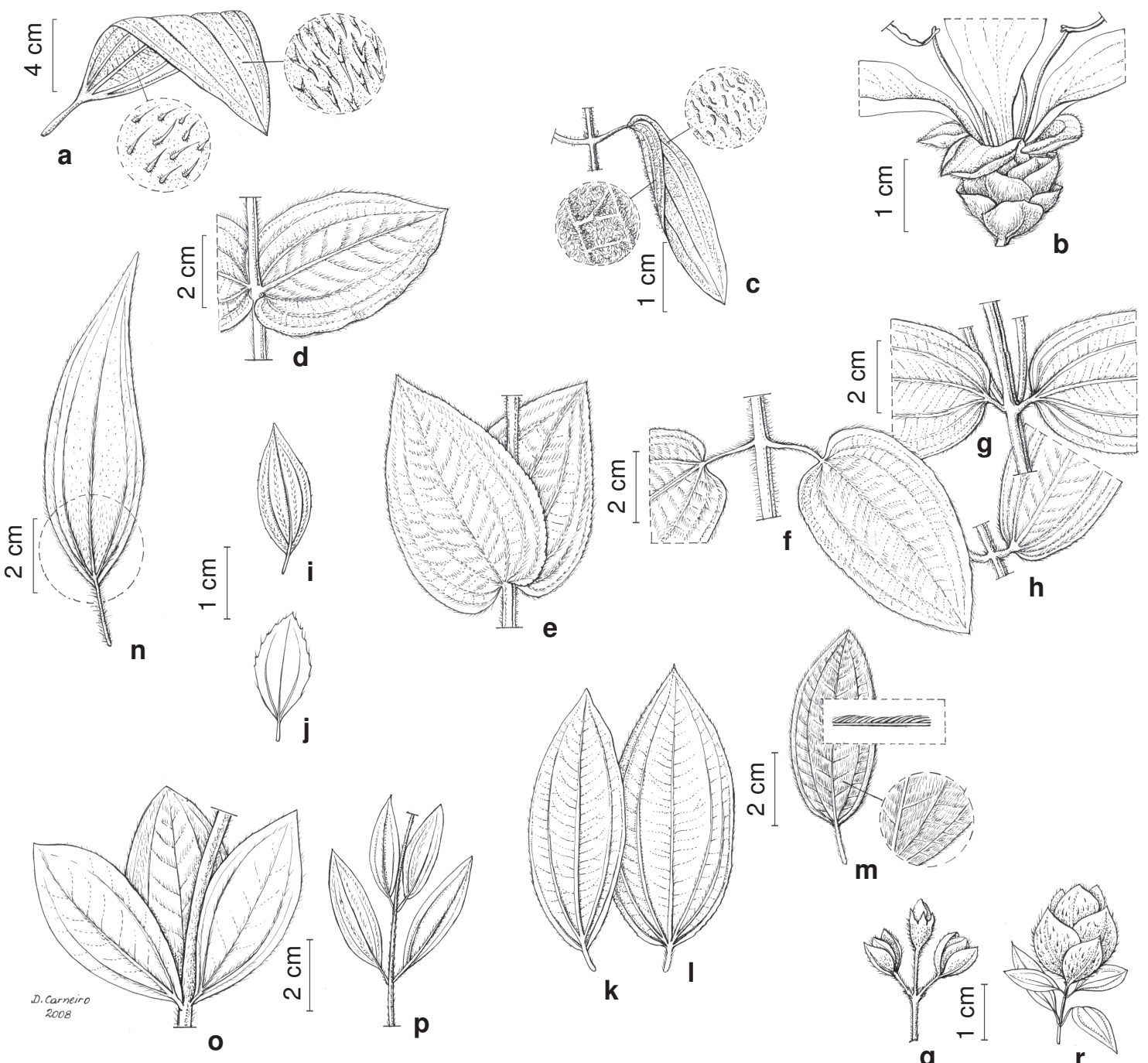

Figura 2 - Detalhes morfológicos de espécies de Tibouchina no Paraná - a. folha de T. granulosa, com detalhe do indumento sobre ambas as faces (Laroca 51). b. brácteas persistentes, localizadas na base do hipanto em T. hatschbachii (Kummrow 3230). c. folha de T. chamissoana, com detalhe do indumento sobre ambas as faces (Ribas 3962). d-e. folhas com a base cordada - d. T. clavata (Hatschbach 42670); e. T. ursina (Hatschbach 18443). f-g. folhas com a base suavemente cordada - f. T. kleinii (Hatschbach 5528); g. T. urvilleana (Silva 287). h. folha com a base arredondada em T. urvilleana (Meyer 529). i. folha e indumento sobre a face adaxial em T. dubia (Hatschbach 18015). j. folha com a face adaxial glabra em T. dubia (Hatschbach 28102). k-1. lâmina e disposição das nervuras - k. T. regnellii (Athayde 40); 1. T. goldenbergii (Kozera 2922). m. lâmina e detalhe do indumento seríceo sobre a face adaxial em T. urvilleana (Hatschbach 25675). n. lâmina e detalhe do indumento de maior dimensão sobre as nervuras primárias, na face adaxial próximo à base em T. pilosa (Hatschbach 40705). o-p. disposição das folhas nos ramos-o. T. frigidula (Hatschbach 42213); p. T. martialis (Hatschbach 23220). q. bractéola em T. trichopoda (Hatschbach 41831). r. galha em T. reitzii (Meyer 211). Figure 2 - Morphological details of Tibouchina species in Paraná - a. leaf of T. granulosa, with detail of the indument on both faces (Laroca 51). b. persistent bracts, at the base of the hypanthium in T. hatschbachii (Kummrow 3230). c. leaf of T. chamissoana, with detail of the indument on both faces (Ribas 3962). d-e. leaves with cordate base - d. T. clavata (Hatschbach 42670); e. T. ursina (Hatschbach 18443). fg. leaves with slightly cordate base - f. T. kleinii (Hatschbach 5528); g. T. urvilleana (Silva 287). h. leaf with rounded base in T. urvilleana (Meyer 529). i. leaf and indument on the adaxial surface in T. dubia (Hatschbach 18015). j. leaf with glabrous adaxial surface in T. dubia (Hatschbach 28102). k-l. blades and venation - k. T. regnellii (Athayde 40); 1. T. goldenbergii (Kozera 2922). m. blade and detail of the sericeous indument on the adaxial surface in T. urvilleana (Hatschbach 25675). n. blade and detail of the indument on the larger primary veins, adaxially and near the base in T. pilosa (Hatschbach 40705). o-p. arrangement of the leaves on the branches - o. T. frigidula (Hatschbach 42213); p. T. martialis (Hatschbach 23220). q. bracteoles in T. trichopoda (Hatschbach 41831). r. gall in T. reitzii (Meyer 211). 
lanceoladas, ápice subulado, precocemente caducas. Flores pentâmeras; hipanto moderadamente estrigosodendrítico, tricomas ca. 0,3 mm compr.; lacínias ca. $5,2 \times 2,5 \mathrm{~mm}$, caducas, ápice agudo ou cuspidado, indumento semelhante ao do hipanto, distribuído na porção mediana; pétalas purpúreas; estames 10 , desiguais, filetes moderada a esparsamente glanduloso seríceo-setosos, tricomas 1-1,3 mm compr. nos dois terços inferiores, prolongamento do conectivo praticamente ausente nos antipétalos, nos antissépalos ca. 0,7 mm compr., apêndices com ápice obtuso, com tricomas glandulares ca. 0,5 mm compr., anteras com ápice subulado; ovário com ápice densamente seríceo, estilete ca. 14,8 mm compr., esparsamente seríceo, tricomas ca. $1 \mathrm{~mm}$ compr. próximo à base. Cápsula ca. 8,7 ×7 mm.

Material selecionado: Curitiba, 8.X.2007, fl. e fr., F.S. Meyer 425 (UPCB).

Tibouchina candolleana pertence ao grupo de espécies que possui estames com apêndices do conectivo revestidos por tricomas glandulares. Pode ser reconhecida pelos tricomas dendríticos com ramificações curtas, que revestem principalmente o hipanto e as lacínias. Originária de florestas ciliares na Bahia, Goiás, Distrito Federal e Minas Gerais (Guimarães \& Oliveira 2009), ocorre apenas sob cultivo no Paraná.

2. Tibouchina cerastifolia (Naudin) Cogn. in Mart. \& Eichler, Fl. bras. 14(3): 403. $1885 . \quad$ Fig. 1d Iconografia: Oliveira (2001, prancha 12)

Erva ou subarbusto 0,3-1 m alt. Ramos jovens quadrangulares, diminutamente alados, não decorticantes, esparsa a moderadamente estrigosos a setulosos, frequentemente tricomas glandulares mesclados. Pecíolo 2-25 mm compr.; lâmina 1,7-8,5 $\times 1,1-3,5 \mathrm{~cm}$, oval ou elíptica, ápice agudo, base obtusa, menos frequentemente aguda, margem crenulada, face adaxial glabra ou moderada a esparsamente estrigosa ou seríceo-estrigosa, tricomas 0,5-2 mm compr., frequentemente com a base imersa no limbo, face abaxial moderadamente setosa ou seríceo-setosa, tricomas 0,5-2 mm compr., raro tricomas glandulares mesclados; nervuras 5-7, pares laterais confluentes. Inflorescência tirsóide, 15-30 flores; bractéolas 2, 1-3×0,5-1,7 mm, ovais ou oblanceoladas, ápice agudo, precocemente caducas. Flores tetrâmeras; hipanto moderada a esparsamente setoso a setuloso, tricomas 0,5-1,5 mm compr., frequentemente tricomas glandulares mesclados; lacínias 1,2-4×1-2,7 mm, persistentes, ápice subulado, glabras ou com indumento semelhante ao do hipanto; pétalas roxas ou róseas; estames 8, desiguais, filetes glabros, prolongamento do conectivo nos antipétalos 0,2-0,5 mm, nos antissépalos 0,4-3,5 mm compr., apêndices com ápice obtuso, glabros, anteras com ápice subulado; ovário com ápice moderada a densamente setuloso ou seríceo, raro tricomas glandulares mesclados; estilete 6-12,5 mm compr., glabro. Cápsula 4,5-11,5×3-5,5 mm.

Material selecionado: Araucária, 1.III.2002, fl. e fr., $C$. Kozera 1528 (UPCB). Balsa Nova, 22.IV.1980, fl. e fr., L.T. Dombrowski 11308 (MBM). Bocaiúva do Sul, 1.V.2000, fl. e fr., O.S. Ribas 3143 (MBM). Campo Mourão, 27.III.2004, fl. e fr., E. Ferreira s.n. (UPCB 48645). Campina Grande do Sul, 22.IV.2007, fl. e fr., $R$. Goldenberg 880 (UPCB). Candói, 11.III.1996, fl. e fr., $Y$. S. Kuniyoshi 5785 (MBM). Capitão Leônidas Marques, 8.IV.2004, fl. e fr., O.S. Ribas 6259 (MBM). Castro, 1.III.1987, fl., R.S. Moro s.n. (HUPG 2353). Clevelândia, 1.V.1966, fl. e fr., J. Lindeman 1127 (MBM). Colombo, 21.II.1995, fl., J.M. Silva 1440 (MBM). Curitiba, 17.IV.2007, fl. e fr., F.S. Meyer 308 (UPCB). Foz do Iguaçú, fl. e fr., 23.V.1979, Buttura 67 (MBM). Guarapuava, 4.II.2006, fl. e fr., J. Cordeiro 340 (UPCB). Inácio Martins, 21.I.1998, fl. e fr., G. Hatschbach 67501 (MBM). Irati, 29.XII.2004, fl., D. Sauressig 494 (UPCB). Jaguariaíva, 14.II.1980, fl. e fr., L.T. Dombrowsky 11146 (MBM). Jundiaí do Sul, 30.III.2001, fl. e fr., J. Carneiro 1110 (MBM). Lapa, 7.III.2002, fl. e fr., O. S Ribas 4565 (MBM). Londrina, 23.III.1997, fl., J.M. Silva 1902 (MBM). Medianeira, 8.XII.1966, fl., J. Lindeman 3475 (MBM). Morretes, 9.IV.1993, fl., G.I. Rizzi 15 (UPCB, HUEM). Pien, 5.III.1984, fl. e fr., T.M. Pedersen 13760 (MBM). Pinhão, 8.III.1996, fl. e fr., S.R. Ziller 1347 (MBM). Piraí do Sul, 27.III.1974, fl. e fr., R. Kummrow 432 (MBM). Piraquara, IV.2005, fl., M. Reginato 402 (UPCB). Ponta Grossa, III.1999, fl. e fr., I.J.M. Takeda s.n. (HUPG 6666). Porto Amazonas, 11.I.1988, fl., S. Ginzbarg 683 (SP). Porto Vitória, 8.XII.1971, fl., G. Hatschbach 28416 (MBM). Prudentópolis, 30.IV.1988, fr., P. R. Rickli s.n. (HUPG 1514). Quatro Barras, 11.III.1996, fl. e fr., A.C. Cervi 6111 (UPCB, MBM). Rolândia, 6.IV.1999, fl., D.A. Estevan 17 (FUEL). Santo Antônio do Sudoeste, 17.V.1977, fl. e fr., G. Hatschbach 39919 (MBM). São Jerônimo da Serra, 27.V.2002, fl., K.L R.V. de Sá 191 (UPCB). São José dos Pinhais, 7.II.1998, fl. e fr., A. Dunaisky 435 (MBM). São Mateus do Sul, 15.III.1974, fl., R. Kummrow 398 (MBM). Tamarana, 22.III.2001, fl., O.C. Pavão s.n. (FUEL 30932). Telêmaco Borba, 9.X.1988, fl. e fr., A.F. Pliessnig s.n. (HUPG 3788). Tijucas do Sul, 23.III.2002, fl., D. Liebsch 416 (UPCB). Tomazina, 24.III.2007, fl. e fr., J.M. Silva 5462 (MBM). União da Vitória, 27.II.1968, fl. e fr., $C$. Koczicki 97 (MBM; UPCB). Vila Alta, 6.XII.1995, fl. e fr., J. Carneiro 107 (MBM).

Tibouchina cerastifolia pode ser reconhecida, dentre as espécies de pequeno porte e que possuem fruto com cálice persistente, por suas folhas de 
formato oval ou elíptico, inflorescências tirsóides com flores tetrâmeras e anteras de ápice subulado. Algumas coletas (J. Cordeiro 340, C. Koczicki 97 e M. Reginato 402) apresentaram variação no número de peças florais, com flores pentâmeras dispostas no centro do dicásio e tetrâmeras nas laterais. Wurdack (1962) encontrou esta mesma variação para alguns espécimes coletados em Santa Catarina e aparentemente os incluiu em Tibouchina longipilosa Cogn. Optamos por incluir tais espécimes em T. cerastifolia, uma vez que os limites estabelecidos para estas espécies são pouco consistentes. É possível que tais espécimes resultem de hibridação entre $T$. cerastifolia e $T$. clinopodifolia, que ocasionalmente ocorrem em simpatria, visto que os mesmos apresentam estados intermediários para características relacionadas às anteras, hipanto e cálice. Tibouchina nitida (Grah.) Cogn. e T. herbacea (DC.) Cogn., espécies citadas para Santa Catarina, foram todas reconhecidas como T. cerastifolia, pois o tamanho do conectivo dos estames antissépalos (caráter distintivo entre $T$. herbacea e T. cerastifolia, segundo Cogniaux, 1891) e a presença ou ausência de tricomas na face adaxial da lâmina (caráter distintivo entre $T$. nitida e T. cerastifolia, segundo Cogniaux, 1891), aparentemente representam apenas variações morfológicas em uma espécie altamente polimórfica. Tibouchina cerastifolia pertence à seção Pseudopterolepis Cogn., que necessita ser revisada, pois a delimitação das espécies apresentase bastante problemática. Possui ampla distribuição e ocorre nos estados do Rio de Janeiro, Minas Gerais, São Paulo, Paraná, Santa Catarina e Rio Grande do Sul (Guimarães \& Oliveira 2009). Viceja nas mais diversas formações vegetacionais do Paraná, tais como áreas abertas ou em regeneração na floresta ombrófila densa, floresta ombrófila mista, floresta estacional semidecidual, estepe gramíneo-lenhosa, savana e refúgio vegetacional altomontano.

\section{Tibouchina chamissoana Cogn. in Mart. \&} Eichler, Fl. bras. 14(3): 403. 1885 . Fig. 2c Iconografia: Guimarães \& Martins (1997, figs. 40-46)

Arbusto 0,8-1,5 m alt. Ramos novos quadrangulares, decorticantes, esparsamente setosos ou vilosos e também moderada a esparsamente glanduloso-pubérulos. Pecíolo 3-8 mm compr.; lâmina 1,7-6,1 $\times 0,8-1,6 \mathrm{~cm}$, discolor, elíptica ou lanceolada, ápice agudo, base obtusa ou suavemente cordada, margem lisa, face adaxial moderadamente setulosa, tricomas $0,4-0,8 \mathrm{~mm}$ compr., frequentemente glandulares mesclados, e também esparsamente glandulosa-pubérula, tricomas ca. 0,2 $\mathrm{mm}$ compr., face abaxial densamente tomentoso-vilosa, tricomas ca. $1 \mathrm{~mm}$ compr., nervuras primárias moderadamente seríceas, tricomas 2,5-3,5 $\mathrm{mm}$ compr.; nervuras 5, confluentes. Cimeira de dicásios, 7-9 flores, ou inflorescência tirsóide, 9-15 flores; brácteolas 2, 3,3-14,1 ×0,6-2,8 mm, lanceoladas, ápice subulado, precocemente caducas. Flores pentâmeras; hipanto moderadamente setoso, tricomas 1-2 mm compr., frequentemente glandulares mesclados, e também esparsamente glanduloso-pubérulo, tricomas ca. 0,2 mm compr.; lacínias 6,3-9,4×1-3,5 mm, caducas, ápice agudo, indumento semelhante ao do hipanto; pétalas purpúreas; estames 10 , desiguais, filetes glabros, prolongamento do conectivo nos antipétalos 0,3-1 mm, nos antissépalos 1,6-3,5 mm compr., apêndices com ápice obtuso, glabros, anteras com ápice subulado; ovário com ápice densamente seríceo ou setoso; estilete 11,7-19,3 mm compr., glabro. Cápsula 7-9 ×5,2-7,2 mm.

Material selecionado: Jaguariaíva, 21.X.1995, fl., D.J. S. Carrião 35 (UPCB). Lapa, 29.XI.2001, fl. e fr., O.S. Ribas 3962 (MBM). Rio Branco do Sul, 6.XII.1995, fl. e fr., G. Hatschbach 64012 (MBM, RB). São Jerônimo da Serra, 12.XII.2002, fl., K.L.R.V. de Sá 414 (FUEL). Sengés, 8.IX.1959, fl. e fr., G. Hatschbach 6279 (MBM). Tibagi, 13.IX.1997, bot. e fl., B.G. Dias s.n. (FUEL 28910).

Tibouchina chamissoana pode ser reconhecida pelas folhas discolores, com face adaxial revestida por tricomas glandulares (em ao menos um dos estratos) e face abaxial densamente tomentoso-vilosa (Fig. 2c). Ocorre nos estados de Minas Gerais, São Paulo e Paraná (Guimarães \& Oliveira 2009), tendo por habitat vegetação de estepe gramíneo-lenhosa e savana.

4. Tibouchina clavata (Pers.) Wurdack, Phytologia 7:233. 1960.

Fig. 2d

Iconografia: Guimarães \& Martins (1997, figs. 62-72)

Arbusto 0,4-1,2 m alt. Ramos jovens quadrangulares, diminutamente alados, não decorticantes, moderadamente seríceos ou estrigosos. Pecíolo ausente ou muito curto, ca. 1 mm compr.; lâmina 3,8-10,5×2,7-8,3 cm, oval, ápice agudo, acuminado ou obtuso, base cordada, margem lisa, face adaxial densamente serícea, tricomas 1,5-2,3 $\mathrm{mm}$ compr., face abaxial densamente serícea ou vilosa, tricomas ca. $2 \mathrm{~mm}$ 
compr., nervuras primárias densamente seríceas, tricomas 2,3-3 mm compr.; nervuras 7-9, confluentes. Inflorescência tirsóide, 15-30 flores; bractéolas 2, 7,4-11,7 × 4,1-7,2 mm, elípticas ou ovais, ápice agudo, precocemente caducas. Flores pentâmeras; hipanto densamente seríceo, tricomas 3-4,5 mm compr.; lacínias 3,8-5 × 2-2,8 mm, caducas, ápice agudo ou cuspidado, indumento semelhante ao do hipanto; pétalas purpúreas; estames 10, desiguais, filetes esparsamente glanduloso-pubérulos, tricomas ca. 0,2 mm compr. na porção inferior, prolongamento do conectivo nos antipétalos 0,3-0,7 mm, nos antissépalos 0,5-1 mm compr., apêndices com ápice obtuso, glabros, anteras com ápice subulado; ovário com ápice densamente seríceo; estilete 14-23,7 mm compr., esparsa a moderadamente glanduloso-pubérulo, tricomas ca. 0,2 mm compr. na porção inferior. Cápsula 10,5-15,5×5-6,2 mm.

Material selecionado: Antonina, 19.XI.1998, fl., G. Hatschbach 68833 (UPCB). Guaraqueçaba, 16.IV.1995, fl., S.F. Athayde 297 (UPCB). Guaratuba, 14.I.2001, fl., W.A. Rodrigues 11326 (UPCB). Matinhos, 20.IX.1964, fl., L.T. Dombrowski 366 (MBM). Morretes, 26.XI.1994, fl., I. Barbola s.n. (UPCB 29030). Paranaguá, 13.XII.1995, fl., Y.S. Kuniyoshi 5749 (EFC). Pontal do Paraná, 15.I.1999, fl., M. Borgo 376 (UPCB).

Tibouchina clavata é reconhecida pelas folhas com indumento seríceo denso em ambas as faces, base da lâmina cordada e pecíolo ausente ou bastante reduzido. Pode ser confundida com $T$. urvilleana, que difere pelas folhas com pecíolo maior (4-10 mm compr.) e conectivo dos estames antissépalos com prolongamento longo (maior que $2 \mathrm{~mm}$ compr.). Tibouchina clavata assemelha-se também a $T$. ursina, que difere pelo indumento avermelhado, com tricomas glandulares mesclados, distribuídos no eixo da inflorescência e hipanto. É conhecida popularmente por "orelha-de-onça", e ocorre no Rio de Janeiro, São Paulo, Paraná e Santa Catarina (Guimarães \& Oliveira 2009). Ocupa áreas com formações pioneiras de influência marinha e floresta ombrófila densa de terras baixas.

5. Tibouchina clinopodifolia (DC.) Cogn. in Mart. \& Eichler, Fl. bras. 14(3): 412. 1885 . Fig. 1b Iconografia: Oliveira (2001, fig. 16)

Erva 20-50 cm alt. Ramos jovens quadrangulares, diminutamente alados, não decorticantes, moderadamente hirsutos, frequentemente tricomas glandulares mesclados. Pecíolo 3-25 mm compr.; lâmina 1,4-7,6 × 1-4 cm, oval ou elíptica, ápice agudo, base obtusa ou aguda, margem crenulada, face adaxial esparsa a moderadamente setosa, tricomas 1,5-4,5 mm compr., base imersa no limbo, face abaxial esparsa a moderadamente setosa, tricomas 1,5-2 mm compr., raro tricomas glandulares mesclados; nervuras 5, confluentes. Cimeira de dicásios, 3-7 flores, ou inflorescência tirsóide, 9-15 flores; bractéolas 2, 1-4,8 × 0,5-1,5 mm, oblongas, elípticas, menos frequentemente ovais, ápice agudo, precocemente caducas. Flores pentâmeras; hipanto moderada a esparsamente setoso, tricomas 0,5-1,5 mm compr., frequentemente glandulares mesclados; lacínias 1$3 \times 1-2 \mathrm{~mm}$, persistentes, ápice agudo, glabras; pétalas róseas; estames 10 , pouco desiguais, filetes glabros, prolongamento do conectivo nos antipétalos ca. 0,1 mm, nos antissépalos ca. 0,3 mm compr., apêndices com ápice obtuso, glabros, anteras com ápice truncado; ovário com ápice esparsamente setuloso; estilete 4,8-5,2 mm compr., glabro. Cápsula 4,1-8×3,6-5,4 mm.

Material selecionado: Adrianópolis, 12.XII.2006, fl. e fr., F.S. Meyer 262 (UPCB). Antonina, 12.I.2006, fl. e fr., O.S. Ribas 7145 (MBM). Bocaiúva do Sul, 23.I.1963, fl. e fr., G. Hatschbach 9700 (MBM). Caiobá, 20.V.1985, fl. e fr., M.T. Shirata 191 (UPCB). Campina Grande do Sul, 12.XI.1968, fr., G. Hatschbach 20280 (MBM). Colombo, 8.VI.2005, fl. e fr., R.F.S. Possete 479 (UPCB). Contenda, 9.XI.1959, fl., A. Mattos (MBM 226095; UPCB 2498). Curitiba, 20.III.2001, fl. e fr., J. Cordeiro 1892 (MBM). Guarapuava, 5.II.1994, fl. e fr., T.M. Pedersen 15953 (MBM). Guaraqueçaba, 7.VIII.2000, fl., N. Josi s.n. (HUEM 5715). Ipiranga, 7.V.1999, fl. e fr., I.J.M. Takeda s.n. (HUPG 760). Jaguariaíva, 5.VII.1933, fr., S.A. Ferreira s.n. (HUPG 4647). Lapa, 8.II.1966, fl., G. Hatschbach 13662 (MBM). Morretes, 20.I.1985, fl. e fr., S. Ferrucci 305 (MBM). Piraquara, X.2004, fl. e fr., M. Reginato 94 (UPCB). Rio Negro, 23.I.1965, fl. e fr., L.B. Smith 14994 (HBR). São José dos Pinhais, 5.VI.1986, fr., J. T. Motta 289 (MBM). São Mateus do Sul, 29.XI.1986, fl. e fr., R.M. Britez 1172 (MBM). Telêmaco Borba, 13.VI.1989, fr., A.O.S. Vieira 321 (FUEL). Terra Boa, 17.II.1961, fl. e fr., E. Pereira 6891 (RB). Tijucas do Sul, 14.II.1974, fl. e fr., R. Kummrow 333 (MBM). Umbará, II.1965, fl., L.T. Dombrowski 1546 (MBM). Tunas do Paraná, 11.XII.2006, fl. e fr., F.S. Meyer 253 (UPCB).

Tibouchina clinopodifolia pertence ao grupo de espécies de pequeno porte, com frutos de lacínias persistentes e flores pentâmeras. Pode ser reconhecida pelas flores com pétalas róseas e anteras com ápice truncado. Uma coleta $(R$. Kummrow 333) apresentou anteras um pouco alongadas e com o ápice menos evidentemente truncado, diferentemente do padrão mais comum. Ocorre no Peru e Brasil, nos estados de Goiás, Rio de Janeiro, Minas Gerais, São Paulo, Paraná, Santa 
Catarina e Rio Grande do Sul (Guimarães \& Oliveira 2009). Tem por habitat áreas abertas, em regeneração, na região da floresta ombrófila densa, floresta ombrófila mista, floresta estacional semidecidual, estepe gramíneo-lenhosa e savana.

6. Tibouchina debilis (Cham.) Cogn. in Mart. \& Eichler, Fl. bras. 14(3): 401. 1885. Fig. 1f, i-j Iconografia: Oliveira (2001, fig. 6)

Erva ou subarbusto 35-60 cm alt. Ramos jovens quadrangulares, diminutamente alados, não decorticantes, esparsa a moderadamente hirsutos ou setosos, raro tricomas glandulares. Pecíolo ausente ou 4,5-7 mm compr.; lâmina 2-7 × 1,2-3,5 $\mathrm{cm}$, oval, elíptica ou lanceolada, ápice agudo, base obtusa ou suavemente cordada, margem crenulada, face adaxial glabra ou esparsa a moderadamente estrigosa, tricomas 1-3 mm compr., base imersa no limbo, raro dispostos apenas próximo à margem, face abaxial esparsa a moderadamente hirsuta ou setosa, tricomas 1-3,5 mm compr.; nervuras 5-7, basais ou com os pares laterais confluentes, par submarginal tênue. Cimeira de dicásios ou inflorescência tirsóide, 7-27 flores, laxa;.bractéolas 2, 2,7-8,1 × 0,7-3 mm, oblongas, oblanceoladas, lanceoladas ou elípticas, ápice agudo, precocemente caducas. Flores pentâmeras; hipanto moderadamente setoso, tricomas 1-4 mm compr., raro glandulares mesclados; lacínias 3,3-6×1,5-2,5 mm, persistentes, ápice agudo ou subulado, glabras ou com indumento semelhante ao do hipanto; pétalas roxas ou purpúreas; estames 10, desiguais, filetes glabros, prolongamento do conectivo nos antipétalos 0,3$0,5 \mathrm{~mm}$, nos antissépalos $2-3 \mathrm{~mm}$ compr., apêndices com ápice obtuso, glabros, anteras com ápice subulado; ovário com ápice esparsa a densamente seríceo ou setuloso; estilete 7-10 mm compr., glabro. Cápsula 9,6-14×3,6-5,6 mm.

Material selecionado: Bocaiúva do Sul, 16.I.2001, fl. e fr., O.S. Ribas 3173 (MBM). Campina Grande do Sul, 10.III.2007, fl. e fr., J.M. Silva 5559 (MBM). Campo Largo, 6.XI.2001, fl., R. Goldenberg 542 (UPCB). Cerro Azul, 5.X.1961, fl. e fr., G. Hatschbach 8419 (MBM). Colombo, 1.XII.1972, fl., L.T. Dowbrowski 4400 (MBM). Contenda, 7.XI.1977, fl. e fr., L.R. Landrum 2429 (MBM). Curitiba, 24.XI.1983, fl. e fr., G. Hatschbach 47562 (MBM). General Carneiro, 26.IV.2002, fr., G. Holowka s.n. (MBM 275903). Guarapuava, 17.XI.1963, fl. e fr., E. Pereira 10581 (MBM, UPCB). Ipiranga, 20.XII.1970, fl., G. Hatschbach 25903 (MBM). Jundiaí do Sul, XII.1997, fl. e fr., J. Carneiro 397 (MBM). Lapa, 29.XI.1990, fl. e fr., I.F. Barbola s.n. (UPCB 18796). Palmas, 16.XI.1998, fl., G. Hatschbach 68718 (UPCB). Palmeira, 5.VII.1997, fl., O.S. Ribas 1874(MBM). Pien, 9.I.1966, fl., G. Hatschbach 13470 (MBM, UPCB).
Piraquara, 19.IV.1972, fl. e fr., N. Imaguire 3040 (MBM). Ponta Grossa, 11.XI.2000, fl., R.S. Moro s.n. (HUPG 9408). Quatro Barras, 22.X.1961, fl., G. Hatschbach 8353 (MBM). São Jerônimo da Serra, 28.X.1999, fl., D.C. Ribeiro 9 (FUEL). Tibagi, 11.XI.1999, fl., M.C. Dias s.n. (FUEL 28924). Tijucas do Sul, 21.X.1977, fl., G. Hatschbach 40432 (MBM). Tunas do Paraná, 11.XII.2006, fl., F. S Meyer 251 (UPCB).

Tibouchina debilis assemelha-se a T. gracilis (Bonpl.) Cogn, especialmente pelos frutos com lacínias persistentes e flores pentâmeras; além disso ambas ocorrem em estepe gramíneo-lenhosa e savana. Tibouchina debilis possui inflorescência laxa, e hipanto setoso, enquanto que em $T$. gracilis as inflorescências são congestas e o hipanto é estrigoso ou seríceo. Cinco coletas provenientes das Serras da Bocaina e Capivari, municípios de Bocaiúva do Sul e Campina Grande do Sul (O.S. Ribas 3173, J.M. Silva 5559, G. Hatschbach 21216 e 26308, C.V. Roderjan 1479) diferem do padrão mais comum encontrado em $T$. debilis, apresentando folhas ovais ou elípticas, com 5-7 nervuras com pares laterais confluentes e pecíolo longo, com 4,5$7 \mathrm{~mm}$ compr. (Fig. 2i), Estes exemplares de certa forma assemelham-se a $T$. cerastifolia, diferindo pelo hipanto mais bojudo e flores exclusivamente pentâmeras. Wurdack (1962) não cita T. debilis para Santa Catarina, embora esta espécie seja citada para o Rio Grande do Sul (Souza 1986). Ocorre na Argentina e Brasil, em São Paulo, Paraná e Rio Grande do Sul (Guimarães \& Oliveira 2009), em áreas em regeneração na região de floresta ombrófila mista, refúgio vegetacional altomontano, estepe gramíneo-lenhosa e savana.

7. Tibouchina dubia (Cham.) Cogn. in Mart. \& Eichler, Fl. bras. 14(3): 415, tab. 72, fig. 2 (como $T$. glazioviana. 1885.

Fig. $2 \mathrm{i}-\mathrm{j}$

Arbusto 0,5-3 m alt. Ramos jovens quadrangulares, não decorticantes, moderadamente estrigosos. Pecíolo 1-4 mm compr.; lâmina 1,3-3,8 $\times 0,6-1,5 \mathrm{~cm}$, oval, elíptica ou lanceolada, ápice agudo, base obtusa, margem lisa ou crenulada, face adaxial glabra ou moderadamente estrigosa, tricomas 0,5-0,8 mm compr., distribuídos em faixas longitudinais nos espaço entre as nervuras, face abaxial moderada a esparsamente estrigosa, tricomas 0,2-0,4 mm compr. distribuídos sobre a superfície, tricomas 0,7-1,2 mm compr. distribuídos sobre as nervuras; nervuras 3, acródromas basais. Flores solitárias ou cimeira de dicásios, 3-5 flores; brácteas ou bractéolas 2, 11-12,5 × 8,5-9,5 mm, ovais ou orbiculares, ápice agudo ou obtuso, precocemente 
caducas. Flores pentâmeras; hipanto esparsa a moderadamente setoso, tricomas 1,5-2 mm compr.; lacínias 3,6-6,5×2,5-4 mm, caducas, ápice agudo, indumento semelhante ao do hipanto; pétalas roxas; estames 10, desiguais, filetes glabros ou esparsamente glanduloso-setulosos, tricomas ca. 0,2 mm compr. na porção basal ou mediana, prolongamento do conectivo nos antipétalos 0,5-2,2 $\mathrm{mm}$, nos antissépalos 1,4-5,7 mm compr., apêndices com o ápice obtuso, glabros, anteras com ápice subulado; ovário com ápice densamente estrigoso; estilete 11,515,5 mm compr., glabro. Cápsula 6-8,2 ×5,5-8 mm. Material selecionado: Balsa Nova, 26.I.1985, fl., P.E. Berry 4468 (MBM). Bocaiúva do Sul, 7.I.2000, fl. e fr., J.M. Silva 3149 (MBM). Campina Grande do Sul, 5.X.1997, fl. e fr., J.M. Silva 2053 (MBM). Campo Largo, 13.II.1999, fl., E.F. Klein 1 (UPCB). Campo Magro, 27.VII.2005, fl., F.E.C. Marinero 11 (MBM). Colombo, 15.XII.1989, fl., V. Nicolack 88 (UPCB). Guaratuba, 12.I.2004, fl., J.M. Silva 3943 (MBM). Lapa, 16.I.2006, fl. e fr., J.M. Silva 4592 (MBM). Morretes, 1.V.2000, fr., M. Scheer 19 (UPCB). Ortigueira, 17.I.1967, fl., G. Hatschbach 15714 (MBM). Palmeira, 28.XI.1993, fl. e fr., E. Takahashi 12 (FUEL). Piraquara, 8.X.2004, fl., E.J. Stange s.n. (UPCB 50434). Ponta Grossa, 23.X.2007, P.B. Schwartsburd 400 (UPCB). Rio Branco do Sul, 13.XII.1996, fl., A.C. Svolenski 322 (EFC). Tibagi, 16.XI.1977, fl., G. Hatschbach 40244 (MBM). União da Vitória, 27.II.1968, fl., C. Koczicki 98 (MBM).

Tibouchina dubia é reconhecida pelo porte arbustivo, flores com pétalas roxas e folhas com face adaxial glabra ou estrigosa, e indumento distribuído em faixas longitudinais, nos espaços entre as nervuras. Assemelha-se a T. reitzii Brade, especialmente pelo hipanto setoso e formato das brácteas, mas esta difere pelas folhas maiores $(1,4-$ $6,8 \times 0,8-2,6 \mathrm{~cm})$, com a face adaxial integralmente recoberta por tricomas. Tibouchina setoso-ciliata Cogn., com tipo proveniente do Paraná, é muito provavelmente um sinônimo de $T$. dubia (P.J.F. Guimarães, obs. pess.). Ocorre em São Paulo, Paraná, Santa Catarina e Rio Grande do Sul (Guimarães \& Oliveira 2009), tendo por habitat áreas de refúgio vegetacional altomontano, floresta ombrófila densa altomontana, estepe gramíneo-lenhosa e savana.

8. Tibouchina dusenii Cogn., Ark. Bot. 9(15): 8; pl. 2. 1910 .

Tibouchina catharinensis Brade, Sellowia 12:

139. 1960. (fide Meyer et al. 2009).

Iconografia: Meyer et al. (2009, fig. 1)

Arbusto 1,5-2 m alt. Ramos jovens quadrangulares, decorticantes, densamente escabrosos. Pecíolo 2-8 mm; lâmina 1,6-5,5×0,9-
1,7 cm, lanceolada ou elíptica, ápice agudo, base aguda ou obtusa, margem crenulada, face adaxial moderadamente escabrosa, tricomas 0,2-0,6 mm compr., face abaxial moderada a densamente escabrosa ou setosa, tricomas 0,5-1 mm compr; nervuras 5, pares laterais confluentes. Cimeira de dicásios, 3-9 flores, congestas; bractéolas 2, 3,8$7,3 \times 5,2-10 \mathrm{~mm}$, orbiculares, ápice obtuso ou emarginado, precocemente caducas. Flores pentâmeras; hipanto densamente setosoescabroso, tricomas 1-1,5 mm compr.; lacínias 4 4,5 ×2,7-3 mm, caducas, ápice obtuso, indumento semelhante ao do hipanto; pétalas brancas; estames 10 , desiguais, filetes moderadamente glandulososetuloso ou glanduloso-seríceos, tricomas ca. 0,6 $\mathrm{mm}$ compr. próximos à base, prolongamento do conectivo nos antipétalos $0,8-1,3 \mathrm{~mm}$, nos antissépalos 2,8-3,5 mm compr., apêndices com ápice obtuso, glabros, anteras com ápice subulado; ovário com ápice densamente seríceo; estilete 10$11 \mathrm{~mm}$ compr., glabro. Cápsula ca. 6,6×6,7 mm.

Material selecionado: Morretes, 11.I.1999, fl. e fr., A.L. Pasdiora 82 (UPCB). Piraquara, 31.I.1971, fl., G. Hatschbach 26190 (MBM, RB). Tunas do Paraná, 26.X.2005, fl. e fr., O.S. Ribas 7040 (MBM).

Tibouchina dusenii pode ser reconhecida pelo porte arbustivo, flores com pétalas brancas e anteras de ápice subulado. Tibouchina hospita também possui porte arbustivo, flores com pétalas brancas e ocorre nas mesmas formações vegetacionais, mas difere por apresentar anteras de ápice truncado. É endêmica do sul do Brasil e ocorre no Paraná e Santa Catarina (Meyer et al. 2009). Ocorre em floresta ombrófila densa altomontana, refúgio vegetacional altomontano e estepe gramíneolenhosa. Tibouchina dusenii está ameaçada de extinção, enquadrando-se na categoria vulnerável (VU), segundo critérios da UICN (2001).

9. Tibouchina fothergillae (Schrank \& Mart. ex DC.) Cogn. in Mart. \& Eichler, Fl. bras. 14(3): 320, tab. 73. 1885 .

Fig. 1r-s, u

Arbusto 1-2,5 m de alt. Ramos jovens quadrangulares, não decorticantes, densa a moderadamente estrigosos. Pecíolo 5-12 mm compr.; lâmina 4,2-8,5 × 1,3-2,4 cm, elípticolanceolada, ápice agudo ou subulado, base obtusa, menos frequentemente acuneada, margem lisa, face adaxial moderadamente estrigosa ou serícea, tricomas 0,3-1,5 mm compr., nervura central moderadamente serícea, tricomas ca. 2 mm compr., distribuídos próximo à base, face abaxial moderadamente serícea ou vilosa, tricomas 0,5-2,5 
mm compr.; nervuras 5, pares laterais confluentes. Cimeira de dicásios, 3-7 flores, ou inflorescência tirsóide, 9-15 flores; bractéolas 2, 16-21 × 8-9,3 $\mathrm{mm}$, ovais, ápice agudo, precocemente caducas. Flores pentâmeras; hipanto moderada a densamente seríceo ou setoso, tricomas 0,8-2,5 mm compr.; lacínias 4,8-6,2×2,8-3,6 mm, caducas, ápice agudo, indumento semelhante ao do hipanto; pétalas roxas ou vinosas; estames 10, desiguais, filetes esparsa a moderadamente glanduloso-pubérulos, tricomas ca. $0,3 \mathrm{~mm}$ compr. na porção inferior, prolongamento do conectivo nos antipétalos 0,7-1,1 mm., nos antissépalos 0,9-1,4 mm compr., apêndices com ápice obtuso, com tricomas glandulares ca. 0,3 mm compr., anteras com ápice subulado; ovário com ápice densamente seríceo; estilete 7-12,5 mm compr., esparsamente setuloso, tricomas ca. $0,5 \mathrm{~mm}$ compr. na porção inferior. Cápsula ca. $7 \times 6 \mathrm{~mm}$.

Material selecionado: Curitiba, 28.III.2007, fl. e fr., F.S. Meyer 291 (UPCB). Londrina, 29.V.1993, fl., C.M. Martins s.n. (UPCB 40346). Maringá, 24.IV.2005, fl., D.C. Rocha s.n. (UPCB 52387). Ponta Grossa, 23.III.1993, fl., C. Bortoli s.n. (HUPG 9194). Quatro Barras, fl., F.S. Meyer 210 (UPCB). Sengés, 12.VII.1993, fl., S.A. Ferreira s.n. (HUPG 7394). Tibagi, 17.IX.2004, fl., M.R.B. do Carmo 969 (UPCB).

No Paraná, Tibouchina fothergillae ocorre apenas sob cultivo, e pode ser reconhecida pelos estames com apêndices revestidos por tricomas glandulares, folhas lanceoladas e hipanto seríceo ou setoso. Os exemplares coletados no Paraná diferem do padrão mais comumente encontrado (de espécimes nativos de São Paulo, Minas Gerais e Espírito Santo) porque possuem folhas com face adaxial serícea, com tricomas maiores e indumento esparso sobre os apêndices do conectivo. A coleta F.S. Meyer 210, efetuada em zona de refúgio vegetacional altomontano no Morro Anhangava, Quatro Barras, também apresentou tais características, mas muito provavelmente seja originária de escape de cultivo. Assemelha-se a $T$. pilosa pelas folhas lanceoladas, bractéolas grandes e hipanto setoso, mas diferencia-se pela ausência de tricomas glandulares nos apêndices dos estames. A coleta Meyer 291, cujas flores apresentam pétalas de coloração vinosa, trata-se de $T$. moricandiana var. vinacea Handro, um provável sinônimo de $T$. fothergillae (P.J.F. Guimarães, obs. pess.). Esta espécie é nativa do Espirito Santo, Rio de Janeiro, Minas Gerais e São Paulo, tendo como ambiente natural as bordas de matas em locais úmidos, em altitudes entre 800 e 1.400 metros (Guimarães \& Oliveira 2009).
10. Tibouchina frigidula (Schrank \& Mart. ex DC.) Cogn. in Mart. \& Eichler, Fl. bras. 14(3): 328, tab. 76. 1885 .

Fig. 2o

Arbusto 0,4-1 m alt. Ramos jovens quadrangulares, não decorticantes, esparsa a moderadamente estrigosos. Pecíolo ausente, folhas geralmente de disposição verticilada, às vezes opostas; lâmina 5-6,2 × 2,4-3 cm, elípticas, ápice agudo ou obtuso, base obtusa, margem lisa, face adaxial glabra ou esparsa moderadamente estrigosa, tricomas 0,2-0,6 mm compr., pouco visíveis, face abaxial esparsa a moderadamente estrigosa, tricomas 0,5-2 mm compr., e ainda esparsamente glandulosopubérulo, tricomas ca. 0,1 mm compr.; nervuras 3-5, se 3 basais, quando 5 os pares laterais confluentes. Inflorescência tirsóide, 9-25 flores; bractéolas 2, 6,88,7 × 2,5-5 mm, elípticas ou oblanceoladas, ápice agudo ou obtuso, precocemente caducas. Flores pentâmeras; hipanto moderadamente estrigoso, tricomas 0,7-1,5 mm compr.; lacínias 5-8 × 2,6-3,8 $\mathrm{mm}$, caducas, ápice obtuso ou cuspidado, indumento semelhante ao do hipanto, distribuído na porção central; pétalas purpúreas; estames 10, desiguais, filetes moderadamente vilosos, tricomas 1-3 mm compr. na porção superior ou mediana, frequentemente glandulares mesclados, prolongamento do conectivo nos antipétalos 0,30,7 mm, nos antissépalos 1,5-2,7 mm compr., apêndices com ápice obtuso, glabros, anteras com ápice subulado; ovário com ápice moderada a densamente estrigoso; estilete 14-18 mm compr., glabro. Cápsula 6-6,5 ×4,5 mm.

Material selecionado: Balsa Nova, 22.IV.1980, fl., L.T. Dombrowski 11304 (MBM). Bocaiúva do Sul, 3.III.2005, fl. e fr., J.M. Silva 4254 (MBM). Campina Grande do Sul, 6.XII.1952, fl., G. Hatschbach 4292 (MBM). Colombo, 15.XII.1989, fl., V. Nicolack 91 (MBM). Curitiba, 9.IV.1963, fl. e fr., E.A. Moreira 376 (MBM). Palmeira, 14.II.2007, fl. e fr., J.M. Silva 5536 (MBM). Ponta Grossa, 17.I.1998, fl., J. Cordeiro 2323 (MBM). Rio Branco do Sul, 5.I.1990, fl. e fr., J.M. Silva 776 (MBM).

Tibouchina frigidula assemelha-se a $T$. martialis Cogn., diferindo pelas folhas maiores, geralmente verticiladas, e inflorescência com maior número de flores e mais laxa. Ocorre em Minas Gerais, São Paulo e Paraná (Guimarães \& Oliveira 2009), tendo por habitat estepe gramíneo-lenhosa e savana.

11. Tibouchina goldenbergii F. S. Mey., P. J. F. Guim. \& C. Kozera, Revta Brasil. Bot. 33(2): 265, figs 1-10. 2010.

Fig. 21

Arbusto 0,7-1 m alt. Ramos jovens quadrangulares, diminutamente alados, decorticantes, 
moderadamente estrigosos. Pecíolo 4,5-5,1 mm compr; lâmina 4,7-7,4×1,8-3,4 cm, oval ou elíptica, ápice agudo, base obtusa, margem lisa, face adaxial moderadamente estrigosa, tricomas ca. $1,8 \mathrm{~mm}$ compr., base imersa no limbo, face abaxial moderadamente serícea ou estrigosa, tricomas ca. 0,8-1 mm compr. sobre a superfície, tricomas $2-2,5 \mathrm{~mm}$ compr. sobre as nervuras primárias; nervuras 7 , primeiro e segundo pares laterais confluentes, par submarginal tênue. Inflorescência tirsóide, 15-30 flores, menos frequentemente cimeira de dicásios, 7-9 flores; bractéolas 2, 11,5-13,7×2,6-3,4 mm, lanceoladas, ápice subulado, precocemente caducas. Flores pentâmeras; hipanto moderadamente seríceo, tricomas ca. $2 \mathrm{~mm}$ compr.; lacínias ca. $10 \times 2 \mathrm{~mm}$, caducas, ápice subulado, indumento semelhante ao do hipanto, tricomas maiores na porção central; pétalas roxas; estames 10, desiguais, filetes moderadamente glanduloso seríceo-vilosos, tricomas $0,5-1,5 \mathrm{~mm}$ compr. na porção mediana, apêndices com ápice obtuso, glabros, prolongamento do conectivo nos antipétalos ca. 1,6 mm, nos antissépalos ca. $4 \mathrm{~mm}$ compr., anteras com ápice subulado; ovário com ápice densamente seríceo; estilete ca. $24 \mathrm{~mm}$ compr., esparsamente seríceo, tricomas ca. 1,6 mm compr. na porção inferior. Cápsula não vista.

Material selecionado: Balsa Nova, 12.II.2008, fl., F.S. Meyer 590 (UPCB).

Tibouchina goldenbergii assemelha-se a $T$. martialis (Cham.) Cogn., diferenciando-se principalmente pelas folhas maiores, com 7 nervuras e hipanto seríceo, com lacínias mais longas. Tem distribuição restrita, ocorrendo exclusivamente em vegetação de estepe gramíneo-lenhosa no Paraná. É bastante rara, com apenas duas coletas (Meyer et al. 2010), e está ameaçada de extinção, enquadrando-se na categoria em perigo crítico (CR), segundo critérios da UICN (2001).

12. Tibouchina gracilis (Bonpl.) Cogn. in Mart. \& Eichler, Fl. bras. 14(3): 386. 1885. Fig. 1k Iconografia: Souza (1986, fig. 33)

Erva ou subarbusto $0,1-1 \mathrm{~m}$ alt. Ramos jovens quadrangulares, diminutamente alados, não decorticantes, moderada a esparsamente estrigosos ou setosos, raro tricomas glandulares mesclados. Pecíolo ausente ou 1-3,5 mm compr.; lâmina 2,3$11,5 \times 0,6-3 \mathrm{~cm}$, elíptica ou lanceolada, ápice agudo, base obtusa, margem crenulada, face adaxial moderadamente estrigosa, tricomas $0,7-3 \mathrm{~mm}$ compr., base imersa no limbo, face abaxial moderadamente serícea, setosa ou estrigosa, tricomas 1,2-4 mm compr., menos frequentemente dendríticos; nervuras 5 , pares laterais confluentes. Inflorescência tirsóide, 9-27 flores, congesta; bractéolas 2, 2,5-16×0,7-4,7 mm, lanceoladas, ápice agudo, precocemente caducas. Flores pentâmeras; hipanto moderadamente estrigoso ou seríceo, tricomas 1,5-3 mm compr., adpressos; lacínias 4,3-5,4×2,2-3 mm, persistentes, ápice agudo, indumento semelhante ao do hipanto; pétalas purpúreas, raro brancas; estames 10, desiguais ou pouco desiguais, filetes glabros, prolongamento do conectivo nos antipétalos $0,2-0,6 \mathrm{~mm}$, nos antissépalos 0,3-3,5 mm compr., apêndices com ápice obtuso, glabros, anteras com ápice subulado; ovário com ápice densamente seríceo; estilete $8-18 \mathrm{~mm}$ compr., glabro. Cápsula 8,5-12×4,3-5 mm.

Material selecionado: Almirante Tamandaré, 10.I.1967, fl., G. Hatschbach 15632 (MBM). Balsa Nova, 16.X.2005, fl., R. Goldenberg 703 (MBM). Campo do Tenente, 10.II.1982, fl., R. Kummrow 1718 (MBM). Campo Largo, 12.III.1999, fl., $R$. Goldenberg 500 (UPCB). Campo Mourão, s.d., fl. e fr., s.c. (HUPG 6495). Castro, XI.1960, fl., E.A. Moreira 10 (HBR, RB, UPCB). Cerro Azul, 19.XI.1983, fl. e fr., S.R.M. Patriota s.n. (SP 338632). Colombo, 12.I.1984, fl. e fr., A. Bidá254 (UPCB). Cruzeiro do Oeste, 29.X.1959, fl. e fr., R. Braga 70 (UPCB). Curitiba, 21.XI.2007, fl., F.S. Meyer 449 (UPCB). Dois Vizinhos, 17.IV.1970, fl. e fr., G. Hatschbach 24150 (MBM). Guaíra, 17.II.1966, fl., J. Lindemann 3278 (MBM). Guarapuava, 16.II.1949, fl. e fr., A.C. Brade 19660 (RB). Guaratuba, 29.I.2004, fl., J.M. Silva 3965 (MBM). Jaguariaíva, 2.XI.1998, fl. e fr., O.S. Ribas 2772 (MBM). Jundiaí do Sul, 3.I.2002, fl. e fr., J. Carneiro 1263 (MBM). Lapa, 18.I.2006, fl. e fr., J.M. Silva 4646 (MBM). Morretes, II.1971, fl. e fr., L.T. Dombrowsky 2654 (MBM). Palmeira, 3.I.1999, fl., G. Bassani 4 (UPCB). Piraí do Sul, 10.XI.1988, fl. e fr., C.R. Dornelles s.n. (HUPG 201). Piraquara, 9.I.2006, fl., M. Reginato 660 (UPCB). Ponta Grossa, 23.X.2004, fl. e fr., P.B. Schwartsburd 392 (UPCB). Porto Amazonas, 22.XII.1963, fl., G. Hatschbach 10854 (MBM). Quatro Barras, 21.I.1999, fl., J. Cordeiro 1493 (FUEL, MBM). Rio Bonito do Iguaçu, 21.IV.1995, fl. e fr., C.B. Poliquesi 272 (MBM). São Jerônimo da Serra, 27.IX.1970, fl., G. Hatschbach 24792 (FUEL, MBM, UPCB). São Mateus do Sul, 7.I.1986, fl., R.M. Britez 276 (MBM). Sengés, 17.I.2007, fl., O.S. Ribas 7491 (MBM). Tibagi, 27.X.2005, fl. e fr., R. Goldenberg 825 (UPCB). Tomazina, 5.II.1997, fl., J. Carneiro 306 (MBM). Vila Alta, 14.XII.1995, fl., S.R. Ziller 1184 (EFC, MBM).

Tibouchina gracilis assemelha-se a T. debilis (ver comentários sob aquela espécie). Apresenta ampla variação morfológica e foi segregada em nove variedades por Cogniaux (1885), estas de difícil reconhecimento (Souza 1986). O conectivo das anteras pode apresentar-se curto ou prolongado e, por mais esta razão, pode ser confundida com $T$. 
debilis. Uma única coleta ( $R$. Goldenberg 825) apresentou flores com pétalas brancas, diferentemente do padrão mais comum, que é o purpúreo. Possui distribuição geográfica ampla, ocorrendo na Guiana, Venezuela, Colômbia, Bolívia, Peru, Brasil, Paraguai, Argentina e Uruguai. No Brasil, ocorre em Mato Grosso, Rio de Janeiro, Minas Gerais, São Paulo, Paraná, Santa Catarina e Rio Grande do Sul (Guimarães \& Oliveira 2009). Ocorre em locais abertos, áreas em regeneração, na floresta ombrófila mista, em estepe gramíneo-lenhosa, savana e refúgio vegetacional altomontano.

13. Tibouchina granulosa (Desr.) Cogn. in Mart. \& Eichler, Fl. bras. 14(3): 332. 1885. Fig. 1x, 2a Iconografia: Guimarães \& Martins (1997, figs. 28-33)

Arvore 2-5 m alt. Ramos jovens quadrangulares, alas bem definidas, decorticantes, moderada a esparsamente estrigosos, raro tricomas dendríticos. Pecíolo 10-22 mm compr.; lâmina 9,5-17,5×3-6,2 $\mathrm{cm}$, elíptica ou lanceolada, ápice agudo, base aguda ou obtusa, margem lisa, face adaxial moderadamente estrigosa, tricomas 1-2 mm compr., com base pustulada mesclados, face abaxial com superfície moderadamente dendrítico-pubescente, tricomas 0,5-1 mm compr., nervuras primárias moderada a esparsamente estrigosas, tricomas 1-2,5 mm compr.; nervuras 5, pares laterais confluentes. Inflorescência tirsóide, 9-30 flores; bractéolas 2, 13,2-15,8 ×6,3$10 \mathrm{~mm}$, ovais ou elípticas, ápice agudo, precocemente caducas. Flores pentâmeras; hipanto densamente seríceo, tricomas 1-2,5 mm compr.; lacínias 8,1-12,1 $\times 3,6-4 \mathrm{~mm}$, caducas, ápice agudo, indumento semelhante ao do hipanto, distribuído na porção central; pétalas roxas ou róseas; estames 10 , desiguais, filetes moderadamente vilosos, tricomas 1-3 mm compr. na porção superior, frequentemente glandulares mesclados, prolongamento do conectivo nos antipétalos 0,7-1 mm., nos antissépalos 1-1,5 mm compr., apêndices com o ápice obtuso, glabros, anteras com ápice subulado; ovário com ápice densamente seríceo; estilete 17,8-22,6 mm compr., glabro. Cápsula 10-12,4×6,8-9,2 mm.

Material selecionado: Campo Mourão, s.d., fl., J.M. de Lima 309 (MBM). Curitiba, 10.III.1975, fl. e fr., S. Laroca 51 (MBM). Cornélio Procópio, 19.VI.1988, fl., L.M. Ceci 2 (FUEL). Jundiaí do Sul, 5.I.1997, fl., J. Carneiro 284 (MBM). Londrina, 20.V.1992, fl., S.H. Sofia s.n. (FUEL 34255). Maringá, V.2001, fl. e fr., S.A. Maglia s.n. (HUEM 10342). Maripá, s.d., fr., s.c. (MBM 259539). Piraquara, 28.VIII.1957, fl., R. Braga 573 (MBM). Ponta Grossa, 27.V.1988, fl., G.J. Ceregato s.n. (HUPG 3833).
No Paraná, T. granulosa ocorre apenas sob cultivo, onde é comumente utilizada para arborização de praças, parques e ruas. Conhecida popularmente como "quaresmeira", pode ser reconhecida pela presença de alas conspícuas nos ramos. Suas pétalas podem variar de róseas a roxas. É nativa do Rio de Janeiro e São Paulo (Guimarães \& Oliveira 2009).

14. Tibouchina guimaraensis Brade, Arch. Jard. Bot. Rio de Janeiro 14: 218. tab. 5, figs. 1-7. 1956.

Fig. $1 \mathrm{~h}$

Erva ou subarbusto $20-50 \mathrm{~cm}$ alt. Ramos jovens quadrangulares, não decorticantes, moderada a densamente lanosos, tricomas longos, aspecto aveludado. Pecíolo ausente; lâmina 4,6-7,2 × 1,3$2,6 \mathrm{~cm}$, elíptica ou oval, ápice agudo, base obtusa, margem crenulada, face adaxial moderadamente vilosa, tricomas $0,7-1,5 \mathrm{~mm}$ compr., face abaxial moderada a densamente lanosa, tricomas 1,5-4,5 mm compr.; nervuras 7 a 9, basais. Inflorescência tirsóide, 9-24 flores, congesta; bractéolas 2, 4,4-12,5 × 1,8$7,4 \mathrm{~mm}$, ovais ou lanceoladas, ápice agudo, precocemente caducas. Flores pentâmeras; hipanto densamente seríceo ou lanoso, tricomas 2-4 mm compr.; lacínias 4-9×1,2-3 mm, persistentes, ápice agudo ou subulado, indumento semelhante ao do hipanto; pétalas purpúreas; estames 10, desiguais, filetes glabros, prolongamento do conectivo nos antipétalos $0,2-0,4 \mathrm{~mm}$, nos antissépalos $0,3-0,5 \mathrm{~mm}$ compr., apêndices com ápice obtuso, glabros, anteras com ápice subulado; ovário com ápice densamente seríceo ou lanoso; estilete 18-20,5 mm compr., glabro. Cápsula 11,5-14,5 ×5,2-5,7 mm.

Material selecionado: Guarapuava, 22.I.1998, fl. e fr., E. Barbosa 101 (MBM). Teixeira Soares, 15.I.1981, fl., G. Hatschbach 43528 (MBM).

Tibouchina guimaraensis assemelha-se a $T$. gracilis, especialmente pelas inflorescências tirsóides com flores congestas. Desta difere pelo revestimento lanoso nos ramos, folhas, bractéolas e hipanto. Tibouchina hassleri Cogn. é muito provavelmente um sinônimo de T. guimaraensis (P.J.F. Guimarães, obs. pess.). Ocorre no Paraguai e Brasil, apenas no estado do Paraná, em estepe gramíneo-lenhosa.

15. Tibouchina hatschbachii Wurdack, Pap. Avulsos Herb. Hatschbach (4): 1. $1963 . \quad$ Fig. 2b Tibouchina marumbiensis Wurdack, Phytologia 55(3): 137. 1984. (fide Meyer et al. 2009). Iconografia: Meyer et al. (2009, fig. 2)

Arbusto 0,8-2 m alt. Ramos jovens quadrangulares, decorticantes, densamente escabrosos ou setosos. Pecíolo 3-16 mm; lâmina 1,6-5,5×1,2- 
3,4 cm, oval, ápice agudo, base obtusa ou suavemente cordada, margem lisa ou crenulada, face adaxial moderadamente estrigosa ou escabrosa, tricomas $0,4-1 \mathrm{~mm}$ compr., frequentemente com base alargada, face abaxial com superfície moderada a densamente velutina, tricomas $0,3-0,5 \mathrm{~mm}$ compr., nervuras primárias e secundárias moderada a densamente escabrosas ou setosas, tricomas 0,51,3 mm compr.; nervuras 5-7, pares laterais confluentes. Flores solitárias; bractéolas ca. 6, 7,3$15,7 \times 8,5-15 \mathrm{~mm}$, orbiculares, ápice obtuso, truncado ou levemente apiculado, persistentes por longo período na flor, localizadas na base do hipanto. Flores pentâmeras; hipanto densamente seríceo, tricomas 1,5-3 mm compr.; lacínias 7,6-13 × 5,1-10,3 mm, caducas, ápice truncado ou acuminado, indumento semelhante ao do hipanto; pétalas purpúreas; estames 10, desiguais, filetes moderadamente glanduloso-setosos, tricomas $0,4-1,2 \mathrm{~mm}$ compr. na porção inferior, prolongamento do conectivo nos antipétalos 0,8-1,4 mm, nos antissépalos 2,5-6,3 mm compr., apêndices com ápice obtuso, glabros, anteras com ápice subulado; ovário com ápice densamente seríceo; estilete 17-23,7 mm compr., glabro, raro esparsamente setuloso, tricomas ca. 0,5 mm compr. na porção inferior. Cápsula 8,7-12,6×8-12 mm.

Material selecionado: Adrianópolis, 22.II.2000, fl. e fr., J.M. Silva 3181 (MBM). Antonina. 25.I.1993, fl. e fr., G. Hatschbach 58528 (HUEM). Jaguariaíva, 21.IV.2007, fl. e fr., F.S. Meyer 316 (UPCB). Morretes, 17.III.1997, fl., M.R.L. Rocha 75 (EFC). Palmeira, 10.III.1989, fl. e fr., $R$. Kummrow 3136 (FUEL). Paranaguá, 20.II.2002, fl., O.S. Ribas 4327 (SP). Piraí do Sul, 17.IV.1987, fl. e fr., Y.S. Kuniyoshi 5154 (EFC, MBM). Ponta Grossa, 16.VIII.2005, fr., $R$. Goldenberg 687 (UPCB). Sengés, 8.IV.1995, fr., M.L. Azevedo s.n. (FUEL 14745). Tibagi, 10.II.1997, fl., V.F. Kinupp 294 (FUEL). Ventania, I.1998, fl., J. Carneiro 428 (MBM).

É reconhecida por suas flores solitárias, envoltas por brácteas persistentes, encontradas na base do hipanto quando em flor e, algumas vezes, em fruto. As folhas apresentam na face adaxial alguns tricomas escabros dispersos, de base alargada. Ocorre apenas no Paraná e porção sul de São Paulo, em refúgios vegetacionais altomontanos associados à floresta ombrófila densa altomontana, e também em estepe gramíneo-lenhosa e savana (Meyer et al. 2009).

16. Tibouchina herincquiana Cogn. in Mart. \& Eichler, Fl. bras. 14(3): 400. tab. 90, fig. 3. 1885.

Erva 20-40 cm alt. Ramos jovens quadrangulares, não decorticantes, moderadamente hirsutos ou setosos, frequentemente tricomas glandulares mesclados. Pecíolo 1-3,5 mm compr.; lâmina 0,9-2,9 × 0,6-2 cm, oval, ápice agudo ou acuminado, raro obtuso, base obtusa ou suavemente cordada, margem crenulada, face adaxial moderadamente serícea, tricomas $0,8-1 \mathrm{~mm}$ compr., face abaxial densa a moderadamente serícea, tricomas 0,9-1,3 mm compr.; nervuras 5, pares laterais confluentes. Cimeira de dicásios, ca. 3-7 flores; bractéolas 2, 3-3,6×0,9-1,4 mm, lanceoladas, ápice agudo, precocemente caducas. Flores pentâmeras; hipanto moderadamente setoso, tricomas 1-2 mm compr., glandulares mesclados; lacínias 3,5-5×11,6 $\mathrm{mm}$, persistentes, ápice agudo ou subulado, indumento semelhante ao do hipanto, distribuído na porção central; pétalas roxas; estames 10 , desiguais, filetes glabros, prolongamento do conectivo nos antipétalos $0,2-0,6 \mathrm{~mm}$, nos antissépalos ca. $2 \mathrm{~mm}$ compr., apêndices com ápice obtuso, glabros, anteras com ápice subulado; ovário com ápice moderada a densamente estrigoso ou seríceo; estilete 10-11 mm compr., glabro ou esparsamente estrigoso, tricomas ca. $0,5 \mathrm{~mm}$ compr. na porção mediana. Cápsula ca. 11-12,5×5 mm.

Material selecionado: Jaguariaíva, 11.I.1973, fl. e fr., G. Hatschbach 31146 (MBM). Piraí do Sul, 30.III.1957, fl. e fr., G. Hatschbach 3849 (MBM). Tibagi, 16.VI.1992, fl. e fr., I.J.M. Takeda 506 (HUPG).

Tibouchina herincquiana apresenta folhas pequenas, seríceas em ambas as faces, flores pentâmeras reunidas em cimeiras de poucas flores, e hipanto setoso, mesclado com tricomas glandulares. Ocorre no Paraná e em São Paulo (Cogniaux 1885). Habita afloramentos de arenito em estepe gramíneolenhosa e savana. Tibouchina herincquiana está ameaçada de extinção, enquadrando-se na categoria vulnerável (VU), segundo critérios da UICN (2001).

17. Tibouchina heteromalla (D. Don) Cogn. in Mart. \& Eichler, Fl. bras. 14(3): 335. tab. 79 (como T. grandiflora). 1885.

Fig. 1q, t

Iconografia: Guimarães \& Martins (1997, como T. grandifolia, figs. 53-58)

Arbusto 1-2 m alt. Ramos jovens quadrangulares, diminutamente alados, não decorticantes, moderadamente seríceos. Pecíolo 520 mm compr.; lâmina 6,2-14×4,5-8 cm, oval, ápice agudo, acuminado ou obtuso, base cordada, margem lisa, face adaxial densamente serícea, tricomas 1-1,5 mm compr., face abaxial com superfície densamente seríceo-vilosa, tricomas ca. $1 \mathrm{~mm}$ compr., nervuras primárias e secundárias densamente setosas, tricomas 1-2 mm compr.; nervuras 7-9, primeiro e segundo pares laterais confluentes. Inflorescência tirsóide, 15-27 flores; bractéolas 2, 5,6-8,2 × 1,7-6,4 
$\mathrm{mm}$, ovais ou lanceoladas, ápice acuminado, precocemente caducas. Flores pentâmeras; hipanto densamente seríceo, tricomas 1-2 mm compr.; lacínias $3,3-5,2 \times 1,5-2,1 \mathrm{~mm}$, caducas, ápice agudo ou cuspidado, indumento semelhante ao do hipanto, tricomas maiores na porção central; pétalas roxas; estames 10, desiguais, filetes esparsamente glanduloso-setulosos, tricomas $0,2-0,4 \mathrm{~mm}$ compr. na porção inferior, prolongamento do conectivo nos antipétalos $0,6-0,9 \mathrm{~mm}$, nos antissépalos $0,9-1,2 \mathrm{~mm}$ compr., apêndices com ápice obtuso, com tricomas glandulares ca. 0,2 mm compr., anteras com ápice subulado; ovário com ápice densamente seríceo; estilete 9-10 mm compr., esparsamente glandulososetuloso ou glanduloso-seríceo, tricomas $0,2-0,8 \mathrm{~mm}$ compr. na porção inferior. Cápsula 5,3-6×3,5-4 mm. Material selecionado: Caiobá, 28.V.1983, fl. e fr., E. R. Duarte 56 (UPCB). Curitiba, s.d., fl. e fr., F.S. Meyer 190 (UPCB). Faxinal, 20.IV.2003, fl. e fr., R.L. Arrias 28 (HUEM). Guaraqueçaba, 23.I.1999, fl. e fr., A.L.S. Gatti 138 (UPCB). Guaratuba, 10.I.1988, fl., J.M. Silva 466 (MBM, UPCB). Ibiporã, 30.IV.1997, fl., L.M. Nunes s.n. (FUEL 28862). Londrina, 7.XII.1992, fl. e fr., L.A. Pires s.n. (FUEL 10193). Moreira Sales, 4.V.2005, fl., S.M. Favaro s.n. (UPCB 52386). Ponta Grossa, 10.I.1987, fl., E.F. Krüger s.n. (HUPG 2192).

Tibouchina heteromalla assemelha-se a $T$. clavata, especialmente pelas folhas ovais, de base cordada, densamente seríceas em ambas as faces. Possui inflorescência mais ramificada, com flores menores, estames com conectivo revestido por tricomas glandulares e folhas pecioladas. As pétalas são roxas, mas em flores recém abertas a porção da unha possui coloração branca. Ocorre no Ceará, Espírito Santo, Goiás, Minas Gerais, Paraíba, Pernambuco, Rio de Janeiro e São Paulo (Guimarães \& Oliveira 2009). No Paraná, foi encontrada apenas sob cultivo, sendo popularmente conhecida como "orelhade-urso" ou "orelha-de-onça". Frequentemente são encontrados exemplares ocorrendo em restinga, originários de cultivos adjacentes. Tibouchina multiflora Cogn. (sinônimo de T. heteromalla; fide Guimarães 1997) é citada por Wurdack (1962), por engano, como nativa de Santa Catarina.

18. Tibouchina hospita (DC.) Cogn. in Mart. \& Eichler, Fl. bras. 14(3): 417. 1885. Fig. 1c Iconografia: Oliveira (2001, fig. 18)

Arbusto ca. $1 \mathrm{~m}$ alt. Ramos jovens quadrangulares, decorticantes, moderadamente estrigosos, raro dendríticos mesclados. Pecíolo 210 mm compr.; lâmina 0,7-4,5×0,4-1,5 cm; elíptica, lanceolada ou oval, ápice agudo, base obtusa, margem crenulada, face adaxial esparsa a moderadamente estrigosa, tricomas $0,4-0,7 \mathrm{~mm}$ compr., restritos aos espaços entre as nervuras e próximo à margem, face abaxial com superfície esparsa a moderadamente estrigosa, tricomas $0,2-0,4 \mathrm{~mm}$ compr., nervuras primárias esparsa a moderadamente estrigosas, tricomas 0,7-1,6 mm compr.; nervuras 3, basais. Cimeira de dicásios, 3-7 flores; bractéolas 2, ca. 2,5-4,5 × $1 \mathrm{~mm}$, oblanceoladas, ápice obtuso, precocemente caducas. Flores tetrâmeras; hipanto moderada a densamente escabroso, tricomas $0,5-$ 1,3 mm compr.; lacínias $2-3,5 \times 1,5-3 \mathrm{~mm}$, persistentes, ápice agudo ou obtuso, indumento semelhante ao do hipanto, distribuído na porção central; pétalas brancas; estames 8 , pouco desiguais, filetes glabros, prolongamento do conectivo em ambos 0,3-0,6 mm compr., apêndices com ápice agudo, glabros, anteras com ápice truncado; ovário com ápice densamente estrigoso; estilete 4-7 mm compr, glabro. Cápsula 4,5-6,8×3,3-5 mm.

Material selecionado: Bocaiúva do Sul, 11.XI.1998, fl. e fr., J.M. Silva 2613 (MBM). Campina Grande do Sul, fr., 3.II.1991, A.P. Tramujas 251 (MBM). Guaratuba, 31.I.1960, fr., G. Hatschbach 6693 (MBM). Morretes, 15.VI.2003, fr., M.B. Scheer 493 (UPCB).

Tibouchina hospita pode ser reconhecida por seu porte arbustivo, flores tetrâmeras com pétalas brancas e anteras de ápice truncado. A face adaxial das folhas é recoberta por indumento estrigoso, distribuído em fileiras nos espaços entre as nervuras primárias. Ocorre no Brasil em Minas Gerais, Rio de Janeiro, São Paulo, Paraná, Santa Catarina e Rio Grande do Sul, em floresta ombrófila densa altomontana e refúgio vegetacional altomontano (Wurdack 1962; Souza 1986; Oliveira 2001).

19. Tibouchina kleinii Wurdack, Sellowia 14: 124. 1962.

Iconografia: Wurdack (1962, fig. 1 g-j)

Arbusto 1-2 $\mathrm{m}$ alt. Ramos jovens quadrangulares, diminutamente alados, não decorticantes, moderada a densamente setosos. Pecíolo 7-20 mm compr.; lâmina 6,2-12,5×2,6-6,2 $\mathrm{cm}$, oval ou lanceolada, ápice agudo, base obtusa ou suavemente cordada, margem crenulada, face adaxial moderadamente estrigosa, tricomas 1-1,7 mm compr., face abaxial com superfície moderadamente setosa ou vilosa, tricomas $0,6-1 \mathrm{~mm}$ compr., nervuras primárias moderadamente setosas, tricomas 1,2-2 mm compr.; nervuras 5-7, pares laterais confluentes, se 7 , último par submarginal tênue. Inflorescência tirsóide, 12-25 flores; bractéolas 2, 4,8-5,7 ×3-3,7 $\mathrm{mm}$, ovais, ápice acuminado, precocemente caducas. Flores pentâmeras; hipanto glanduloso-setoso, 
tricomas 0,8-1,5 mm compr.; lacínias 2-3,6×1,7-3 $\mathrm{mm}$, caducas, ápice cuspidado, indumento semelhante ao do hipanto, distribuído na porção central; pétalas roxas; estames 10, desiguais, filetes glabros ou raro esparsamente pubérulos, tricomas ca. $0,2 \mathrm{~mm}$ compr. na porção inferior, prolongamento do conectivo nos antipétalos 1,5-2 mm, nos antissépalos ca. 2,6 mm compr, apêndices com ápice obtuso, glabros, anteras com ápice subulado; ovário com ápice densamente seríceo ou setoso, frequentemente tricomas glandulares mesclados; estilete 17-18 mm compr., esparsa a moderadamente glanduloso-pubérulo, tricomas ca. $0,2 \mathrm{~mm}$ compr. na porção inferior. Cápsula 9-10×6 mm.

Material selecionado: Pien, 3.II.1964, fl. e fr., G. Hatschbach 10923 (MBM, UPCB). Rio Negro, 19.II.1988, fl. e fr., G. Hatschbach 51886 (FUEL, MBM, UPCB).

Tibouchina kleinii assemelha-se a T. pilosa Cogn. por suas folhas lanceoladas, grandes, e hipanto com tricomas setosos. Diferencia-se daquela pela ausência de tricomas longos na nervura central próximo à base da face adaxial das folhas, inflorescência tirsóide, maior número de flores e bractéolas menores. É endêmica do sul do Brasil, ocorrendo apenas no Paraná e em Santa Catarina, em estepe gramíneo-lenhosa e áreas abertas, em regeneração, na região de floresta ombrófila mista (Meyer 2008). Tibouchina kleinii está ameaçada de extinção, enquadrando-se na categoria vulnerável (VU), segundo critérios da UICN (2001).

20. Tibouchina martialis (Cham.) Cogn. in Mart. \& Eichler, Fl. bras. 14(3): 346, tab. 80, fig. 2. 1885.

Fig. 1a, 2p

Iconografia: Guimarães \& Martins (1997, figs. 1-7)

Arbusto $0,8-1,5 \mathrm{~m}$ alt. Ramos jovens quadrangulares, decorticantes, moderada a esparsamente estrigosos. Pecíolo 1-4 mm compr.; lâmina 1,8-3,2 ×0,7-1,4 cm, elíptica, oblonga ou lanceolada, ápice agudo, base obtusa, menos frequentemente aguda, margem lisa, face adaxial moderadamente estrigosa, tricomas ca. $1 \mathrm{~mm}$ compr., face abaxial com superfície esparsa a moderadamente estrigosa, tricomas ca. 0,5 mm compr., e também esparsamente glanduloso-pubérula, tricomas ca. 0,1 $\mathrm{mm}$ compr., nervuras primárias moderada a esparsamente estrigosas, tricomas $0,7-1,2 \mathrm{~mm}$ compr.; nervuras $3-5$, se 3 basais, quando 5, com pares laterais confluentes. Cimeira de dicásios, 3-7 flores, ou inflorescência tirsóide 9-15 flores; bractéolas 2, 3,4-5,6×0,9-1,3 mm, lanceoladas, ápice subulado, precocemente caducas. Flores pentâmeras; hipanto moderadamente estrigoso, tricomas $0,8-1,3 \mathrm{~mm}$ compr.; lacínias 3,6-6,4×2,1-3,9 mm, caducas, ápice cuspidado, indumento semelhante ao do hipanto, distribuído na porção central; pétalas roxas ou purpúreas; estames 10, desiguais, filetes moderada a densamente vilosos, tricomas 1-3 mm compr., na porção mediana, frequentemente glandulares mesclados, prolongamento do conectivo nos antipétalos 0,4-0,8 mm, nos antissépalos 2,2-3,9 mm compr, apêndices com ápice obtuso, glabros, anteras com ápice subulado; ovário com ápice densamente seríceo; estilete 13,6-16,8 mm compr., glabro ou moderada a esparsamente seríceo, tricomas 1,3-1,7 $\mathrm{mm}$ compr. na porção inferior, raro glandulares mesclados. Cápsula 6,1-7×4-5,3 mm.

Material selecionado: Almirante Tamandaré, 10.I.1967, fl., G. Hatschbach 15635 (MBM, UPCB). Arapoti, 5.XII.1990, fl. e fr., G. Hatschbach 54881 (MBM). Balsa Nova, 4.I.1965, fl., G. Hatschbach 12076 (MBM). Bocaiúva do Sul, 27.XII.1963, fl., G. Hatschbach 10816 (MBM). Campo Largo, 3.I.1978, fl., G. Hatschbach 41082 (MBM). Campo Magro, 25.II.2003, fl., O.S. Ribas 5115 (MBM). Castro, 15.I.1965, fl. e fr., L.B. Smith 14488 (HBR). Cerro Azul, 25.I.1974, fl., G. Hatschbach 33764 (MBM). Ipiranga, 16.III.1972, fl., G. Hatschbach 29320 (MBM). Jaguariaíva, 21.IV.2006, fl. e fr., F.S. Meyer 312 (UPCB). Lapa, 29.XI.2001, fl., O.S. Ribas 3951 (MBM). Piraí do Sul, 24.XI.1987, fl., G. Hatschbach 51680 (UPCB). Ponta Grossa, 13.XII.1969, fl., G. Hatschbach 23220 (MBM). Rio Branco do Sul, 5.I.1990, fl., J.M. Silva 773 (SP). São Jerônimo da Serra, 13.II.2002, fr., K.L.R.V. de Sá 500 (FUEL). Sengés, 6.X.1971, fl., G. Hatschbach 27104 (MBM). Tibagi, 27.X.2005, fl. e fr., R. Goldenberg 821 (UPCB). Ventania, 7.XII.2004, fl., D.A. Estevan 548 (UPCB). Wenceslau Braz, 23.III.1968, fl. e fr., $G$. Hatschbach 18920 (MBM).

Tibouchina martialis assemelha-se a $T$. frigidula e Tibouchina goldenbergii (ver comentários sob aquelas espécies). A coleta $G$. Hatschbach 23220, identificada como T. riedeliana Cogn. por Guimarães (1997), foi aqui reconhecida como T. martialis, com base em um coleta depositada no herbário MBM. Como Guimarães (1997) cita apenas as duplicatas depositadas nos herbários $\mathrm{C}$ e $\mathrm{MO}$, existe a possibilidade de mistura de materiais. Ocorre na Venezuela, Colômbia e Brasil, no Mato Grosso, Goiás, Distrito Federal, São Paulo e Paraná (Guimarães 1997). Tem por habitat vegetação de estepe gramíneo-lenhosa e savana.

21. Tibouchina pilosa Cogn. in Mart. \& Eichler, Fl. bras. 14(4): 600. 1888.

Fig. 2n

Arbusto 2-4 malt. Ramos jovens quadrangulares, diminutamente alados, não decorticantes, moderada 
a densamente hirsutos ou setosos. Pecíolo 6-21 mm compr.; lâmina 3,8-15,5 × 1,5-3,5 cm, lanceolada, ápice agudo, base obtusa, margem crenulada, face adaxial moderadamente seríceo-estrigosa, tricomas 0,5-1 mm compr., nervura central próximo à base moderadamente serícea, tricomas 1,5-2 mm compr., maiores que os da superfície, face abaxial moderadamente setulosa ou estrigosa, tricomas 0,50,8 mm compr, nervuras primárias moderadamente setosas ou seríceas, tricomas 1,5-2 mm compr.; nervuras 5, pares laterais confluentes. Cimeira de dicásios, 3-7 flores; bractéolas 2, 10-19,5 ×6,4-10,3 $\mathrm{mm}$, ovais ou elípticas, ápice agudo, precocemente caducas. Flores pentâmeras; hipanto moderadamente setoso, tricomas 1,2-2,5 mm compr.; lacínias 1,2-4× 2,4-3,2 mm, caducas, ápice agudo ou cuspidado, indumento semelhante ao do hipanto; pétalas roxas; estames 10, desiguais, filetes esparsa a moderadamente glanduloso-setulosos, tricomas 0,2-0,4 mm compr. na porção inferior, prolongamento do conectivo nos antipétalos 0,5-1,5 mm compr., nos antissépalos 4,47 mm compr., apêndices com ápice obtuso, glabros, anteras com ápice subulado; ovário com ápice densamente seríceo; estilete 17-23,2 mm compr., glabro ou moderadamente setoso a setuloso, tricomas $0,5-1,2 \mathrm{~mm}$ compr. na porção inferior. Cápsula 7,7-10,5×6-7,8 mm.

Material selecionado: Adrianópolis, 12.XII.2006, fl., F.S. Meyer 258(UPCB). Antonina, 6.I.1992, fl., G. Hatschbach 56153 (MBM). Bocaiúva do Sul, 1993, fr., A. Soares 27 (MBM). Campina Grande do Sul, 13.IV.1971, fr., G. Hatschbach 26714 (MBM). Cerro Azul, 20.II.1981, fl., G. Hatschbach 43633 (MBM). Colombo, 8.II.1984, fl., A. Bidá 265 (UPCB). Guaratuba, 12.II.1980, fl., P.I. Oliveira 208 (MBM). Morretes, 11.V.1992, fr., A.C. Cervi 3695 (UPCB). Piraquara, II.2005, fl. e fr., R. Goldenberg 684 (UPCB). Quatro Barras, 4.VI.1996, fr., A.L. Schutz 43 (UPCB). Rio Branco do Sul, 10.I.1978, fl., G. Hatschbach 40705 (MBM). São José dos Pinhais, 7.II.1998, fl., A. Dunaisky 438 (MBM). Tijucas do Sul, 20.II.1989, fl. e fr., A.C. Cervi 2605 (MBM, UPCB). Tunas do Paraná, 11.XII.2006, fl., F.S. Meyer 254 (UPCB).

Tibouchina pilosa assemelha-se a $T$. fothergillae (ver comentários sob aquela espécie). É endêmica do sul do Brasil ocorrendo apenas no Paraná e em Santa Catarina (Meyer 2008). Tem como habitat floresta ombrófila densa submontana e montana, sendo popularmente conhecida por "manacá".

22. Tibouchina pulchra (Cham.) Cogn. in Mart. \& Eichler, Fl. bras. 14(3): 301. tab. 68. 1885.

Fig. 1g, 1-m

Árvore 3-8 m de altura. Ramos jovens quadrangulares, não decorticantes, moderadamente estrigosos. Pecíolo 5-20 mm compr.; lâmina 3,8-10,2 $\times$ 1,4-3,4 cm, elíptica, ápice agudo, base aguda ou obtusa, margem lisa, ambas as faces moderadamente estrigosas, tricomas 0,2-0,5 mm compr.; nervuras 5, basais ou com a nervura central e primeiro par lateral levemente supra-basais, raro par submarginal tênue. Flores solitárias; brácteas 4-6, 12,3-12,5 × 7,8-10,7 $\mathrm{mm}$, em forma de capuz, ápice levemente dobrado sobre o botão, precocemente caducas. Flores solitárias, pentâmeras; hipanto densamente seríceo, tricomas 1,2-3,3 mm compr.; lacínias 9,1-10,5 ×4,7$5,1 \mathrm{~mm}$, caducas, ápice obtuso, indumento semelhante ao do hipanto, distribuído na porção central; pétalas com coloração mutável, inicialmente brancas, posteriormente róseas; estames 10 , desiguais, filetes antipétalos glabros, raro com indumento semelhante ao dos filetes antissépalos, filetes antissépalos moderadamente glandulososetulosos, tricomas $0,5-1,3 \mathrm{~mm}$ compr. na porção superior, prolongamento do conectivo nos antipétalos 0,8-1 mm, nos antissépalos 3,8-5,2 mm compr., apêndices com ápice obtuso, glabros, anteras com ápice subulado; ovário com ápice densamente seríceo; estilete 22,6-29 mm compr., moderada a esparsamente seríceo, tricomas 0,5-2 mm compr. na porção inferior. Cápsula 10-13,4×12-14,5 mm.

Material selecionado: Adrianópolis, 12.XII.2006, fl. e fr., F. S. Meyer 260 (UPCB). Antonina, 19.XI.1998, fl., G. Hatschbach 68850 (UPCB, MBM). Guaraqueçaba, 23.XII.1999, fl., G. Gatti 575 (UPCB). Guaratuba, 25.XII.1976, fl., G. Hatschbach 39311 (MBM, SP). Londrina, 27.XI.1989, fl., M.M. Sobreira s.n. (FUEL 7933). Morretes, 30.XI.1984, fl., F.C. da Silva 729 (UPCB). Paranaguá, 2.XI.1986, fl. e fr., W.S. Souza 363 (MBM, FUEL). Quatro Barras, 28.VI.2005, fl., E. Barbosa 1038 (MBM).

Tibouchina pulchra é reconhecida por suas brácteas em forma de capuz, com ápice levemente dobrado sobre o botão, flores solitárias, com pétalas de coloração mutável e estilete revestido por indumento seríceo. Assemelha-se a T. sellowiana, que também possui flores solitárias e pétalas de coloração mutável. No entanto, $T$. sellowiana possui folhas com 3 nervuras, flores menores e estilete glabro, enquanto T. pulchra possui folhas com 5 nervuras, flores maiores e estilete com tricomas. Algumas coletas, em especial de municípios em zona de transição entre as florestas ombrófilas densa e mista, apresentaram características intermediárias entre $T$. sellowiana e T. pulchra, tais como três nervuras conspícuas e duas tênues, estilete com pouco indumento, às vezes esparso e somente próximo à base. Popularmente é conhecida como "jacatirão", 
"quaresmeira” ou "manacá-serrano". Ocorre no Rio de Janeiro, São Paulo, Paraná e Santa Catarina (Guimarães \& Oliveira 2009). No Paraná, foi coletada em floresta ombrófila densa, nas formações de terras baixas, submontana e montana, sendo muitas vezes utilizada para arborização de cidades.

23. Tibouchina regnellii Cogn. in Mart. \& Eichler, Fl. bras.14(3): 305. 1885.

Fig. 2k

Árvore $2-7 \mathrm{~m}$ alt. Ramos jovens quadrangulares, não decorticantes, moderadamente estrigosos. Pecíolo 3-15 mm compr.; lâmina 2,4-8,5 ×1,2-3,4 cm, elíptica, ápice agudo ou obtuso, base aguda ou obtusa, margem lisa, ambas as faces moderadamente estrigosas, tricomas 0,3-1 mm compr.; nervuras 5, pares laterais confluentes. Cimeira de dicásios, 5-7 flores; bractéolas 2, 8,6-15×6,2-10,3 mm, elípticas ou em forma de capuz, ápice obtuso ou levemente dobrado sobre o botão, precocemente caducas. Flores pentâmeras; hipanto densamente seríceo, tricomas 1,3-2,2 mm compr.; lacínias 6,7-10,2 ×2,7-4,6 mm, caducas, ápice obtuso ou levemente acuminado, indumento semelhante ao do hipanto, distribuído na porção central; pétalas roxas, com a porção da unha branca; estames 10, desiguais, filetes glabros ou esparsamente glanduloso-setulosos, tricomas ca. 0,5 $\mathrm{mm}$ compr. na porção superior, prolongamento do conectivo nos antipétalos 0,4-1,3 $\mathrm{mm}$, nos antissépalos 1,5-5,3 mm compr., apêndices com ápice obtuso, glabros, anteras com ápice subulado; ovário com ápice densamente seríceo; estilete 19,7-23,4 mm compr., glabro ou esparsamente seríceo, tricomas 0,5-1,2 mm compr. na porção inferior. Cápsula 5,2$10 \times 4,7-9,4 \mathrm{~mm}$.

Material selecionado: Antonina, 30.IX.1977, fl., G. Hatschbach 40201 (MBM). Caiobá, fl., 11.IV.1974, R. Kummrow 549 (MBM). Guaraqueçaba, 10.III.2002, fl., F. Putini s.n. (MBM 297876). Guaratuba, 10.III.1972, fl., G. Hatschbach 29297 (MBM). Matinhos, 6.IX.1999, fl., A. Dunaisky 1301 (MBM). Morretes, 13.XII.1979, fl. e fr., L.T. Dombrowski 10985 (MBM). Paranaguá, 22.II.1995, fl., S.R. Ziller 733 (MBM). Pontal do Paraná, 27.II.2001, fl., J. Carneiro 1079 (MBM).

Tibouchina regnellii assemelha-se a $T$. pulchra por apresentar porte arbóreo, folhas elípticas com 5 nervuras, flores grandes e hipanto seríceo. Diferem principalmente por $T$. regnellii apresentar flores reunidas em inflorescências e pétalas de coloração permanentemente roxa (apenas com a região da unha de coloração esbranquiçada). Ocorre em São Paulo (Guimarães \& Oliveira 2009) e Paraná, em vegetação pioneira de influência marinha e na floresta ombrófila densa, nas formações de terras baixas e submontana.
24. Tibouchina reitzii Brade, Sellowia 12: 137. tab. 2, figs. 1-13. 1960.

Fig. 2r

Arbusto 0,5-3 m alt. Ramos jovens quadrangulares, decorticantes, moderadamente estrigosos. Pecíolo 3-11 mm compr.; lâmina 1,4-6,8 $\times 0,8-2,6 \mathrm{~cm}$, elíptica, lanceolada, menos frequentemente oval, ápice agudo, base aguda ou obtusa, margem lisa, face adaxial moderadamente estrigosa, tricomas 0,6-1 mm compr., frequentemente tricomas de base imersa no limbo, face abaxial moderadamente estrigosa, tricomas $0,3-0,6 \mathrm{~mm}$ compr., nervuras primárias moderadamente estrigosas, tricomas 0,7-1 mm compr.; nervuras 3-5, se 3 basais, quando 5, pares laterais confluentes. Flores solitárias ou dispostas em cimeira de dicásios, ca. 3-5 flores; brácteas ou bractéolas 2, 14,5-19×9$11,5 \mathrm{~mm}$, orbiculares, ápice acuminado ou obtuso, precocemente caducas. Flores pentâmeras; hipanto moderada a esparsamente setoso, tricomas 1,5-3 mm compr.; lacínias 5-7,3×3,3-4,3 mm, caducas, ápice obtuso ou agudo, indumento semelhante ao do hipanto, distribuído na porção central; pétalas roxas, estames 10, desiguais, filetes glabros ou esparsamente glanduloso-setulosos, tricomas ca. 0,3 mm compr. na porção basal, prolongamento do conectivo nos antipétalos 0,7-1,1 mm, nos antissépalos 4,2-7 mm compr., apêndices com ápice obtuso, glabros, anteras com ápice subulado; ovário com ápice densamente estrigoso; estilete 10-19 mm compr., glabro. Cápsula 7-9,2×5,6-8,4 mm.

Material selecionado: Antonina, 10.I.1994, fl. e fr., $G$. Hatschbach 59791 (FUEL, MBM). Bocaiúva do Sul, 16.I.2004, fl. e fr., O.S. Ribas 5785 (MBM). Campina Grande do Sul, 4.II.1985, fl., P.I. Oliveira 866 (MBM). Curitiba, s.d., fl. e fr., P.K Dusén 3579 (R). Guaraqueçaba, 5.VII.2001, fr., M. Scheer 324 (UPCB). Guaratuba, 12.I.2004, fl., J.M. Silva 3936 (MBM). Morretes, 1.V.2000, fr., A.L. Pasdiora 83 (UPCB). Piraquara, 9.I.2004, fl. e fr., O.S. Ribas 5744 (MBM). Quatro Barras, 10.X.2006, fl., F.S. Meyer 225 (UPCB). São José dos Pinhais, 3.II.1967, fl. e fr., G. Hatschbach 15959 (MBM, UPCB). Tijucas do Sul, 28.XII.1958, fl., G. Hatschbach 5386 (MBM).

Tibouchina reitzii pode ser confundida com T. dubia (ver comentários sob aquela espécie). Em várias exsicatas observou-se a formação de galhas nas porções terminais dos ramos. As galhas apresentam um revestimento de aspecto foliáceo, semelhante às brácteas e bractéolas, inclusive com o mesmo tipo de indumento que reveste a face abaxial das mesmas (Fig. 2r). Diferem das estruturas reprodutivas porque têm projeções foliares numerosas (ca. 9-12), e não possuem botão floral em sua porção central. Ocorre em São Paulo, Paraná e Santa Catarina (Guimarães \& Oliveira 2009), em refúgio vegetacional 
altomontano e na floresta ombrófila densa, nas formações montana e altomontana.

25. Tibouchina riedeliana Cogn. in Mart. \& Eichler, Fl. bras. 14(3): 368. tab. 87, fig. 2. 1885.

Iconografia: Guimarães \& Martins (1997, figs. 47-52)

Arbusto 1-2 m alt. Ramos jovens quadrangulares, decorticantes, moderadamente estrigosos. Pecíolo 3,8-5,4 mm compr.; lâmina 1,7$3,6 \times 0,6-1,2 \mathrm{~cm}$, elíptica, ápice agudo ou obtuso, base obtusa, margem lisa, ambas as faces moderadamente estrigosas, tricomas ca. 0,3-0,7 mm compr.; nervuras 5 , pares laterais confluentes. Cimeira de dicásios, 5-9 flores; bractéolas 2, 6,4-7,2 ×3,9 mm, ovais ou elípticas, ápice obtuso ou acuminado, precocemente caducas. Flores pentâmeras; hipanto densamente seríceo, tricomas 1,5-2 mm compr.; lacínias 5,5-7,5 $\times 2,9-3,4 \mathrm{~mm}$, caducas, ápice obtuso ou acuminado, indumento semelhante ao do hipanto, distribuído na porção central; pétalas roxas; estames 10 , desiguais, filetes esparsa a moderadamente glandulososetuloso ou glanduloso-viloso, tricomas ca. 0,4$0,8 \mathrm{~mm}$ compr. na porção mediana ou por toda extensão dos filetes, prolongamento do conectivo nos antipétalos ca. 0,7-0,9 mm, nos antissépalos ca. 2,5-2,8 mm compr., apêndices com ápice obtuso, glabros, anteras com ápice subulado; ovário com ápice densamente seríceo; estilete ca. 14,6-15,2 mm compr., glabro ou esparsamente seríceo, tricomas 11,5 mm na porção basal. Cápsula 6,6-9,7×5-6,5 mm. Material selecionado: Tibagi, 13.XII.1996, fl. e fr., J.M. Silva 1826 (MBM).

Tibouchina riedeliana assemelha-se a $T$. martialis pelas folhas elípticas, pelas lacínias do cálice com indumento distribuído na porção mediana e filetes com indumento longo, mas difere pelo hipanto seríceo e bractéolas maiores e elípticas. Tibouchina riedeliana também assemelha-se a T. hatschbachii, especialmente pelos ramos decorticantes e hipanto com revestimento seríceo, diferindo desta pelas flores em inflorescências e duas bractéolas menores e precocemente caducas. O tipo da espécie (Riedel 1426, isótipo NY) tem hipanto com tricomas mais engrossados (tendendo a estrigosos), e um pouco mais esparsos do que nas coletas paranaenses. Tibouchina riedeliana ocorre no Rio de Janeiro, São Paulo e Paraná(Guimarães \& Oliveira 2009). No estado do Paraná foi coletada exclusivamente em vegetação de estepe gramíneo-lenhosa, no Parque Estadual do Guartelá. Tibouchina riedeliana está ameaçada de extinção, enquadrando-se na categoria em perigo crítico (CR), segundo critérios da UICN (2001).
26. Tibouchina saxicola F.S. Mey. P.J.F. Guim. \& R. Goldenb., Hoehnea 36(1): 144. fig. 3. 2009.

Fig. 1e

Erva $20-40 \mathrm{~cm}$ alt. Ramos jovens quadrangulares, diminutamente alados, não decorticantes, moderada a esparsamente setulosos, frequentemente tricomas glandulares mesclados. Pecíolo 1-4 mm compr.; lâmina $1,3-5 \times 0,2-0,8 \mathrm{~cm}$; lanceolada, ápice e base agudos, margem crenulada, face adaxial glabra ou esparsa a moderadamente estrigosa, tricomas $0,8-1,1 \mathrm{~mm}$ compr., face abaxial com as nervuras primárias e secundárias esparsamente setulosas, tricomas $0,5-1,2 \mathrm{~mm}$ compr; nervuras 3, basais. Inflorescência tirsóide, 12-25 flores, ou cimeira de dicásios, 7-9 flores; bractéolas 2, 2-10 $\times 0,7-3,5 \mathrm{~mm}$, oblanceoladas ou elípticas, ápice obtuso, precocemente caducas. Flores tetrâmeras; hipanto esparsa a moderadamente setuloso, tricomas 0,4-1 $\mathrm{mm}$ compr., frequentemente tricomas glandulares mesclados; lacínias 1,7-3×1,1-2,4 mm, persistentes, ápice subulado, glabras; pétalas purpúreas; estames 8 , desiguais, filetes glabros, prolongamento do conectivo nos antipétalos $0,2-0,4 \mathrm{~mm}$, nos antissépalos 1,2-2,5 mm compr., apêndices com ápice obtuso, glabros, anteras com ápice subulado; ovário com ápice esparsamente setuloso; estilete 8,8-10,2 mm compr., glabro. Cápsula 7,7-8,5×3,4-4 mm.

Material selecionado: Jaguariaíva, 17.XII.2000, fl. e fr., L. Lisingen 141 (UPCB).

Tibouchina saxicola assemelha-se a $T$. cerastifolia especialmente pelas inflorescências tirsóides com flores tetrâmeras, pelo hipanto alongado e setuloso, frequentemente com tricomas glandulares mesclados, e estames antissépalos com conectivo longamente prolongado. Difere dela especialmente pelas folhas lanceoladas, com três nervuras de disposição basal. É endêmica do Paraná (Meyer et al. 2009), ocorrendo exclusivamente em savana, ocupando fendas no arenito às margens do Rio Jaguariaíva e Rio das Mortes. Tibouchina saxicola está ameaçada de extinção, enquadrando-se na categoria em perigo crítico (CR), segundo critérios da UICN (2001).

27. Tibouchina sellowiana (Cham.) Cogn. in Mart. \& Eichler, Fl. bras. 14(3): 304. tab. 69, fig. 2. 1885.

Fig. 1n-o

Árvore 2-8 m alt. Ramos jovens quadrangulares, não decorticantes, moderada a esparsamente estrigosos. Pecíolo 3-15 mm compr.; lâmina 2,3-10× 0,9-3,5 cm, elíptica, ápice e base agudos, margem lisa, ambas as faces moderadamente estrigosas, tricomas ca. $0,3 \mathrm{~mm}$ compr.; nervuras 3 , basais ou levemente suprabasais. Flores solitárias; brácteas 4-6, 9,5-13,5 
× 6-10,7 mm, em forma de capuz, ápice levemente dobrado sobre o botão, precocemente caducas. Flores pentâmeras; hipanto densamente seríceo, tricomas 1,2-2 mm compr.; lacínias 5,3-8,4 × 3,1-4,8 mm, caducas, ápice obtuso, indumento semelhante ao do hipanto, distribuídos na porção central; pétalas com coloração mutável, inicialmente brancas, posteriormente róseas; estames 10 , desiguais, filetes antipétalos glabros ou com indumento semelhante ao dos filetes antissépalos, filetes antissépalos esparsamente glanduloso-setulosos, tricomas 0,2-0,5 mm compr. na porção mediana, prolongamento do conectivo nos antipétalos 0,7-1,7 $\mathrm{mm}$, nos antissépalos 3,6-6,2 mm compr., apêndices com ápice obtuso, glabros, anteras com ápice subulado; ovário com ápice densamente seríceo; estilete 17-25 mm compr., glabro. Cápsula 6,4-9,7×6,2-8,3 mm.

Material selecionado: Balsa Nova, 29.IV.1985, fl., $R$. Kummrow 2605 (MBM). Bocaiúva do Sul, 28.III.1941, fl., G.N. Ceccatto 12 (MBM, RB). Campina Grande do Sul, 7.IV.1967, fl., G. Hatschbach 16255 (MBM, UPCB). Colombo, 14.III.1984, fl., A. Bidá 386 (UPCB). Curitiba, 24.IV.1992, fl. e fr., L.M.C. Bahls s.n. (HUPG 1713). Faxinal, 20.IV.2003, fl., R.L. Arrias 27 (HUEM). Morretes, 9.IV.1993, fl. e fr., M.E. Rosalino 2 (HUEM, UPCB). Palmeira, 17.V.1979, fl., L.T. Dombrowski 10527 (MBM). Piraquara, III.2005, fl. e fr., M. Reginato 217 (UPCB). Pinhal, 10.III.1997, fl. e fr., A. Lacerda 124 (UPCB). Ponta Grossa, 17.V.1989, fl. e fr., D. Schiesinsky s.n. (HUPG 3954). Quatro Barras, 10.X.2006, fr., F.S. Meyer 224 (UPCB). Sapopema, 29.III.1997, fl., V.F. Kinupp 353 (RB, SP). São Jerônimo da Serra, 30.X.1998, fl., E.M. Francisco s.n. (RB 345446). São José dos Pinhais, 23.II.1968, fl. e fr., C. Koczicki 88 (MBM, UPCB). Sengés, 16.IV.1971, fl. e fr., G. Hatschbach 26756 (MBM). Tamarana, 26.IV.1986, fl., F.F. Leão s.n. (RB 345449). Telêmaco Borba, 1.IV.1995, fl., S.A. Filipaki s.n. (UPCB 33107). Tibagi, 25.III.2005, fl. e fr., M.R.B. do Carmo 850 (UPCB). Ventania, 4.V.2004, fl., D.A. Estevan 389 (UPCB).

Tibouchina sellowiana assemelha-se a $T$. pulchra (ver comentários sob aquela espécie). Ocorre no Brasil no Rio de Janeiro, Minas Gerais, São Paulo, Paraná, Santa Catarina e Rio Grande do Sul (Guimarães \& Oliveira 2009). No Paraná, foi coletada em floresta ombrófila mista, estepe gramíneo-lenhosa e savana.

28. Tibouchina trichopoda (DC.) Baill., Adansonia 12: 75.1877.

Iconografia: Cogniaux (1885, tab. 74)

Arbusto 1-3 malt. Ramos jovens quadrangulares, diminutamente alados, decorticantes, moderada a esparsamente estrigosos. Pecíolo 4-14 mm compr.; lâmina 2,7-5,8 ×1,1-2,4 cm, elíptica, ápice agudo, base aguda ou obtusa, margem lisa, face adaxial moderadamente estrigosa, tricomas 0,3-0,5 mm compr., face abaxial moderadamente estrigosa, tricomas $0,5-$ 0,8 mm compr., nervuras primárias moderadamente setosas ou setulosas, tricomas 1,2-1,7 mm compr.; nervuras 3-5, se 3 basais, quando 5, pares laterais confluentes. Cimeira de dicásios, 3-7 flores; bractéolas 2, 3,9-7,2 × 3,2-6 mm, ovais ou orbiculares, ápice acuminado, precocemente caducas. Flores pentâmeras; hipanto moderadamente setoso ou escabroso, tricomas 0,7-1 mm compr., frequentemente glandulares mesclados; lacínias 3-4,8 × 2,4-3,5 mm, caducas, ápice agudo, indumento semelhante ao do hipanto; pétalas roxas; estames 10, desiguais, filetes glabros ou esparsamente glanduloso-setulosos, tricomas ca. 0,4 mm compr., próximo à base, prolongamento do conectivo nos antipétalos $0,5-$ 1,6 mm, nos antissépalos 2,5-5,7 mm compr., apêndices com ápice obtuso, glabros, anteras com ápice subulado; ovário com ápice esparsamente estrigoso ou seríceo, frequentemente tricomas glandulares mesclados; estilete 11-19 mm compr., glabro. Cápsula 4,5-6×5,3-6,5 mm.

Material selecionado: Antonina, 12.I.1989, fl., O.S. Ribas 30 (UPCB, MBM). Caiobá, 1.VII.1950, fl., A. Mattos s.n. (RB 125807). Guaraqueçaba, 9.V.1996, fl. e fr., Y.S. Kuniyoshi 5855 (EFC). Guaratuba, 7.X.2000, fl., W.A. Rodrigues 11310 (UPCB). Matinhos, I.1946, fl., J.J. Bigarella s.n. (MBM 226372). Morretes, 28.I.1987, fl.e fr., J. Cordeiro 405 (MBM). Paranaguá, 6.XI.1997, fl. e fr., M. Barddal 34 (EFC). Pontal do Sul, 12.XII.1995, fl., Y.S. Kuniyoshi 5703 (EFC). Pontal do Paraná, 13.V.1997, fl., J.H. Pedrosa-Macedo s.n. (UPCB 31417).

Tibouchina trichopoda assemelha-se a $T$. reitzii, que também apresenta folhas elípticas e hipanto revestido por indumento setoso, mas diferencia-se especialmente pelas bractéolas de menor dimensão (Fig. 2q). Popularmente, é conhecida como "jacatirão do brejo", pois muito frequentemente viceja em locais onde a água permanece acumulada. Ocorre no Espírito Santo, Rio de Janeiro São Paulo, Paraná, Santa Catarina e Rio Grande do Sul (Guimarães \& Oliveira 2009). No Paraná, foi coletada na região litorânea, nas formações pioneiras de influência marinha e em áreas em regeneração em floresta ombrófila densa de terras baixas.

29. Tibouchina ursina (Cham.) Cogn. in Mart. \& Eichler, Fl. bras. 14(3): 351. $1885 . \quad$ Fig. 2e Iconografia: Guimarães \& Martins (1997, figs. 34-39)

Arbusto 0,4-1 m alt. Ramos jovens quadrangulares, diminutamente alados, não decorticantes, densamente hirsutos ou setosos, frequentemente tricomas glandulares mesclados. 
Pecíolo ausente ou muito curto, ca. de $1 \mathrm{~mm}$ compr.; lâmina 4-10,2 × 2,6-5,2 cm, oval, ápice agudo ou acuminado, base cordada, margem lisa, face adaxial moderada a densamente serícea, tricomas 1-2 mm compr., frequentemente com a base imersa no limbo, face abaxial moderada a densamente serícea, superfície com tricomas $1-1,8 \mathrm{~mm}$ compr., nas nervuras primárias com tricomas $2-3,5 \mathrm{~mm}$ compr.; nervuras 7-9, basais. Inflorescência tirsóide, 12-30 flores; bractéolas 2, 11,0-29,3×4,8-16,3 mm, ovais, ápice agudo, precocemente caducas. Flores pentâmeras; hipanto moderada a densamente seríceo, tricomas 1,5-3 mm compr., frequentemente tricomas glandulares mesclados; lacínias 8-9,5 ×2-3,5 mm, caducas, ápice agudo ou subulado, indumento semelhante ao do hipanto; pétalas roxas; estames 10, desiguais, filetes glabros ou esparsamente glanduloso-setulosos, tricomas $0,2-0,6 \mathrm{~mm}$ compr. na porção mediana, prolongamento do conectivo nos antipétalos 0,5-0,8 mm, nos antissépalos 1-2 $\mathrm{mm}$ compr., apêndices com ápice obtuso, glabros, anteras com ápice subulado; ovário com ápice moderadamente glanduloso-setuloso; estilete 17,226,1 mm compr., glabro. Cápsula 10,3-11,8×5-6 mm. Material selecionado: Araucária, II.1941, fl., N. Santo s.n. (R 166056). Balsa Nova, 21.III.1988, fl. e fr., A.C. Cervi. s.n. (UPCB 19224). Campo Largo, 12.III.1999, fl. e fr., $R$. Goldenberg 498 (UPCB). Campo do Tenente, 25.I.1968, fl., G. Hatschbach 18443 (MBM). Curitiba, 14.III.1986, fl., J.M. Silva 100 (FUEL). Guaratuba, 18.II.1998, fl., E.P. Santos 456 (MBM). Imbituva, 5.III.1982, fl. e fr., $R$. Kummrow 1863 (MBM). Irati, 25.III.1950, fl., E.S. Araújo s.n. (R 150058). Jaguariaíva, 21.IV.2007, bot., F.S. Meyer 350 (UPCB). Lapa, 18.I.1979, fl., G. Hatschbach 41939(MBM). Palmas, 9.II.1949, fl. e fr., $R$. Dansereau 2 (R). Palmeira,10.II.2004, fl., E. Barbosa 848 (MBM). Piraquara, 1.II.2005, fl., T. Lobato 9 (MBM). Ponta Grossa, 8.III.2005, fl. e fr., P.B. Schwartsburd 689 (UPCB). Quatro Barras, 21.I.1999, fl., J. Cordeiro 1497 (FUEL 28049). São Jerônimo da Serra, 13.II.2003, fl., K.L.R.V. de Sá499(FUEL). Tamarana, 22.III.2001, fl., O.C. Pavão s.n. (FUEL 30932). Tibagi, 7.IV.1995, fr., M.C. Dias 37 (FUEL).

Tibouchina ursina assemelha-se a T. clavata (ver comentários sob aquela espécie). Ocorre no Brasil, em Minas Gerais, São Paulo, Paraná e Santa Catarina (Guimarães \& Oliveira 2009). No Paraná, foi coletada em refúgios vegetacionais altomontanos, estepe gramíneo-lenhosa e savana.

30. Tibouchina urvilleana (DC.) Cogn. in Mart. \& Eichler, Fl. bras. 14(3): 358, tab. 84, fig. 2. 1885.

Fig. 1w, 2g-h, m

Arbusto 1-2,5 m alt. Ramos jovens quadrangulares, diminutamente alados, não decorticantes, moderadamente seríceos. Pecíolo 4 $10 \mathrm{~mm}$; lâmina 5,5-7,8×2-4,2 cm, oval ou elíptica, ápice agudo, base obtusa ou suavemente cordada, margem lisa, face adaxial densamente serícea, tricomas 1-1,5 mm compr., face abaxial densamente serícea, superfície com tricomas 1,5-2 mm compr., nervuras primárias com tricomas 2-3,2 mm compr.; nervuras 5-7, pares laterais confluentes. Inflorescência tirsóide, 15-30 flores; bractéolas 2, 9,4-10,5×5,7-6,7 mm, elípticas ou ovais, ápice agudo, precocemente caducas. Flores pentâmeras; hipanto densamente seríceo, tricomas 2-3 mm compr.; lacínias ca. $6 \times 2,5 \mathrm{~mm}$, caducas, ápice agudo, indumento semelhante ao do hipanto; pétalas roxas; estames 10, desiguais, filetes esparsamente glandulososetulosos, tricomas ca. $0,3 \mathrm{~mm}$ compr. na porção inferior, prolongamento do conectivo nos antipétalos 0,7-1,5 mm, nos antissépalos 2,5-4 mm compr., apêndices com ápice obtuso, glabros, anteras com ápice subulado; ovário com ápice densamente seríceo; estilete 22,4-23,2 mm compr., esparsamente setuloso ou seríceo, tricomas $0,2-1 \mathrm{~mm}$ compr. na porção inferior, frequentemente glandulares mesclados. Cápsula 9,4-10×5,7 mm.

Material selecionado: Guaraqueçaba, 14.IV.1995, fl. e fr., S.F. Athayde 287 (FUEL). Paranaguá, 22.XI.1986, fl. e fr., $R$ M. Britez 1126 (MBM, FUEL).

Tibouchina urvilleana assemelha-se a $T$. clavata, especialmente pelo indumento seríceo sobre ambas as faces da folha e do hipanto, mas difere pelas folhas com pecíolos maiores e estames antissépalos com conectivo longamente prolongado (2,5-4 mm compr.). A base das folhas pode variar entre as formas obtusa (Fig. 2h) a suavemente cordada (Fig. 2g). Popularmente é conhecida por "orelha-de-onça", devido ao aspecto piloso de suas folhas. Ocorre no Brasil, em São Paulo, Paraná, Santa Catarina e Rio Grande do Sul (Guimarães \& Oliveira 2009). Tem por habitat as formações pioneiras de influência marinha, ou áreas abertas, em regeneração, em floresta ombrófila densa de terras baixas.

\section{Agradecimentos}

A Gert Hatschbach e demais membros da equipe do Museu Botânico Municipal (MBM) e aos curadores dos herbários citados pelos empréstimos e permissões para consultas, a Rosana Romero e Ana Odete dos Santos Vieira pelas valiosas sugestões ao texto, a Diana Carneiro pelas ilustrações, a Fabián Michelangeli pelas fotografias do tipo de Tibouchina riedeliana Cogn. O terceiro autor recebe bolsa produtividade do CNPq. 


\section{Referências}

Camargo, E.A. \& Goldenberg, R. 2007. O gênero Leandra, seção Leandraria (Melastomataceae) no Paraná. Iheringia, série Botânica 62: 105-113.

Clausing, G. \& Renner, S.S. 2001. Molecular phylogenetics of Melastomataceae and Memecylaceae: implications for character evolution. American Journal of Botany 88: 486-498.

Cogniaux, A. 1883-85. Melastomataceae. In: Martius, C. F. P. \& Eichler, A. W. \& Urban, I. (eds.). Flora brasiliensis. Vol. 14. F. Fleischer, Lipsiae. Pars 3, pp. 1-510; pars 4, pp. 1-656.

Cogniaux, A. 1891. Melastomataceae. In: de Candolle, A. \& de Candolle, C. Monographiae Phanerogamarum. Vol. 7. G. Masson, Paris. Pp. 1-1256.

Goldenberg, R. 2004. O gênero Miconia (Melastomataceae) no estado do Paraná, Brasil. Acta Botânica Brasílica 18: 927-947.

Guimarães, P.J.F. 1997. Estudos taxonômicos de Tibouchina sect. Pleroma (D.Don) Cogn. (Melastomataceae). Tese de Doutorado. Universidade Estadual de Campinas, Campinas. 191p.

Guimarães, P.J.F. \& Martins, A. 1997. Tibouchina sect. Pleroma (D.Don) Cogn. (Melastomataceae) no estado de São Paulo. Revista Brasileira de Botânica 20: 11-33.

Guimarães, P.J.F. \& Oliveira, C.M.S. 2009. Tibouchina Aubl. In: Martins, S.E.; Wanderley, M.G.L.; Sheperd, G.J.; Giulietti, A.M. \& Melhem, T.S. (eds.). Flora fanerogâmica do estado de São Paulo. Vol. 6. FAPESP, São Paulo. Pp. 127-149.

Hickey, M. \& King, C. 2000. The Cambridge illustred glossary of botanical terms. Cambridge University Press, Cambridge. 208p.

Holmgren, P.K. \& Holmgren, N.H. 2009. Index Herbariorum: A global directory of public herbaria and associated staff. Disponível em <http:// sweetgum.nybg.org/ih/>. Acesso em 12 maio 2008.

Maack, R. 1968. Geografia física do estado do Paraná. BADEP/UFPR/IBTP, Curitiba. 350p.
Meyer, F.S. 2008. O gênero Tibouchina Aubl. (Melastomataceae) no estado do Paraná. Dissertação de Mestrado. Universidade Federal do Paraná, Curitiba. 114p.

Meyer, F.S.; Guimarães, P.J.F. \& Goldenberg, R. 2009. Uma nova espécie de Tibouchina Aubl. (Melastomataceae) e notas taxonômicas sobre o gênero no estado do Paraná, Brasil. Hoehnea 36: 139-147.

Meyer, F.S.; Guimarães, P.J.F. \& Kozera, C. 2010. Uma nova espécie de Tibouchina Aubl. (Melastomataceae), endêmica do Paraná, Brasil. Revista Brasileira de Botânica 33: 265-269.

Oliveira, C.M.S. 2001. Tibouchina sect. Diotanthera, Diplostegia, Pseudopterolepis, Purpurella e Simplicicaules (Melastomataceae) no estado de São Paulo. Dissertação de Mestrado. Universidade Estadual de Campinas, Campinas. 127p.

Peralta, P. 2002. Las espécies del gênero Tibouchina (Melastomataceae) en Argentina. Darwiniana 40: 107-120.

Renner, S.S. 1993. Phylogeny and classification of the Melastomataceae and Memecylaceae. Nordic Journal of Botany 13: 519-540.

Roderjan, C.V.; Kuniyoshi, Y.S. \& Galvão, F. 1993. As regiões fitogeográficas do estado do Paraná. Acta Forestalia Brasiliensis 1: 3-6.

Souza, M.L.D.R. 1986. Estudo taxonômico do gênero Tibouchina Aubl. (Melastomataceae) no Rio Grande do Sul, Brasil. Insula 16: 3-108.

Todzia, C. \& Almeda, F. 1991. A revision of Tibouchina section Lepidotae (Melastomataceae-Tibouchineae). Proceedings of the California Academy of Sciences 47: 175-206.

UICN, 2001. Categorías y criterios de la Lista Roja de la UICN: vérsion 3.1. UICN, Gland y Cambridge. $38 \mathrm{p}$.

Wurdack, J.J. 1962. Melastomataceae of Santa Catarina. Sellowia 14: 109-217.

Lista de exsicatas:

Amaral, W. 359 (12). Anjos, R.A.M. 20 (6). Aoki, P. 9 (15). Araújo, A.G. 7 (13). Arrias, R.L. 27 (27), 28 (17). Athayde, S.F. 12 (22), 40 (23), 70 (22), 71 (4), 274 (28), 275 (23), 281 (23), 287 (30). Barddal, M. 34 (28). Barbosa, E. 101 (14), 218 (7), 848 (29), 1038 (22). Barros, C.R.M.B. 6 (4). Bassani, G. 4 (12). Berry, P.E. 4468 (7). Bidá, A. 254 (12), 265 (21), 386 (27), 549 (5). Borgo, M. 376 (4). Brade, A.C. 19493 (7), 19622 (6). Braga, P.I.S. 2318 (23), 2632 (28). Braga, R. 70 (12), 121 (6), 201 (6), 503 (6), 573 (13), 1635 (4), 1651 (2). Britez, R.M. 243 (4), 276 (12), 283 (5), 1065 (23), 1121 (28), 1172 (5). Carauta, J.P.P. 3064 (7). Carmo, M.R.B. 850 (27), 864 (29), 969 (9).Carneiro, J. 107 (2), 284 (13), 306 (12), 397 (6), 428 (15), 1032 (12), 1075 (23), 1079 (23), 1110 (2), 1263 (12). Carrião, D.J.S. 35 (3). Ceccatto, G. 12 (27), 39 (12), 43 (20). Ceci, L.M. 2 (13). Cervi, A.C. 1967 (2), 2091 (24), 2262 (5), 2345 (4), 2421 (5), 2436 (22), 2438 (22), 2605 (21), 2624 (2), 2625 (27), 2705 (6), 2916 (6), 2965 (12), 2966 (3), 3277 (20), 3563 (20), 3818 (12), 3845 (20), 3695 (21), 4013 (25), 4019 (15), 4180 (20), 5972 (3), 6111 (2), 6406 (7), 6521 (20), 6457 (28), 6548 (22), 6659 (5), 6570 (22), 8230 (27), 8385 (23), 8549 (7). Cordeiro, J. 238 (15), 339 (22), 340 (2), 405 (28), 685 (7), 1020 (10), 1141 (10), 1172 (9), 1271 (24), 1367 (7), 1424 (2), 1490 (12), 1493 (12), 1497 (29), 1885 (2), $1892(5), 2323(10)$. Cruz, J. 144 (6). Dansereau, P. 2 (29). Dias, M.C. 37 (29). Dittrich, V.A. 84 (27), 104 (5). Dombrowski, L.T. 55 (6), 125 (12), 152 (12), 195 (5), 203 (27), 223 (5), 261 (12), 264 (5), 288 (28), 331 (7), 366 (4), 500 (5), 766 (6), 784 (6), 901 (6), $916(7), 918$ (2), 939 (27), 962 (6), 1017 (6), $1107(4), 1134(10), 1144(4), 1241(12), 1270(12), 1285(27), 1304(12), 1429(6), 1434(24), 1528(12), 1530(29), 1546(5), 2239(12), 2585(12), 2644$ (4), 2654 (12), 2683 (2), 2684 (27), 2689 (2), 2781 (9), 2843 (28), 2866(2), 2872 (27), 3138 (6), $3182(22), 3861$ (6), $3874(2), 4400$ (6), 4462 (12), 4540 (27), 4545 (27), 4577 (29), 4579 (2), 4584 (12), 4609 (12), 4916 (12), 4940 (5), 4951 (6), 5079 (5), 5171 (27), 5176 (2), 5248 (2), 5420 (6), 5473 (5), $5502(6), 5504(12), 5536(6), 5568(6), 5583(12), 5588(12), 5653(12), 5677(12), 5695(6), 5702(12), 5704(12), 5852(29), 5910(29), 5971(29), 5995$ 
(27), 6151 (6), 6152 (5), 6201 (2), 6215 (12), 6225 (12), 6271 (29), 6276 (5), 6290 (5), 6822 (12), 6919 (7), 6926 (6), 6921 (12), 6956 (12), 6960 (12), 6990 (12), 7014 (27), 7092 (29), 7464 (23), 7526 (23), 8808 (6), 9015 (12), 9329 (22), 9340 (22), 9394 (4), 9414 (29), 9552 (2), 9878 (3), 10127 (12), $10133(29), 10141$ (12), 10527 (27), $10628(4), 10822(29), 10895(23), 11055$ (29), $11079(12), 11145(29), 11146(2), 11308(2), 11334(28), 11972(3)$, 12468 (7), 12720 (1), 13111 (5), 13543 (27), 13709 (29), 13710 (23), 14327 (27). Dornelis, L.P. 2 (27). Duarte, E.R. 56 (17). Dunaisky, A. 435 (2), 438 (21), 1301 (23). Dusén, P.K. 3309 (22), 3359 (21), 3470 (7), 3579 (24), 3777 (8). Estevan, D.A. 17 (2), 210 (20), 389 (27), 548 (20). Ferruci, S. 305 (5). Filho, H.M. 75 (6), 439 (12). Freitas, O. 6 (4). Furtado, P.P. 191 (27). Gatti, A.L. S. 115 (4), 138 (17), 139 (28), 163 (5), 235 (5). Gatti, G. 6 (24), 245 (28), 260 (5), 312 (5), 389 (23), 575 (22). Gentry, A. 49753 (12). Ginzbarg, S. 683 (2). Goldenberg, R. 498 (29), 500 (12), 542 (6), $618(24), 620$ (2), 680 (2), 684 (21), 687 (15), 703 (12), 821 (20), 823 (12), 825 (12), 880 (2). Gonçalves, R. 171 (20). Gouveia, M.F. 4 (2). Hatschbach, G. 36 (10), 150 (18), 312 (5), 555 (12), 564 (7), 610 (29), 639 (27), 642 (2), 1248 (21), 1673 (4), 1742 (18), 1750 (7), 1855 (21), $1878(12), 2177$ (2), 2736 (8), 3622 (5), 3624 (15), $3628(29), 3849$ (16), 4292 (10), 5068 (3), 5073 (20), $5386(24), 5400$ (28), $5528(19), 5555(7)$, $6279(3), 6550(20), 6590$ (7), $6693(18), 6694(24), 6813$ (24), $7646(24), 8353(6), 8419$ (6), 8540 (5), $8726(12), 8832(15), 8837(21), 8892(20), 9053$ (23), 9594 (7), $9700(5), 9716(14), 9717$ (6), $10816(20), 10840$ (24), $10854(12), 10861(6), 10923(19), 11272(15), 11295(28), 11804(20), 11879(7)$, $11942(20), 12076(20), 12094(7), 12175(20), 12259(16), 12283(3), 12391(2), 12897(3), 13470(6), 13500(10), 13622(5), 13838(2), 14120(5), 15632$ (12), 15635(20), 15714(7), 15959(24), 16010(28), 16028(29), 16104(19), 16138(21), 16202(21), 16255(27), 17632(20), 17467(5), $18015(7), 18018$ (10), 18058(20), 18217 (7), 18343(14), 18443 (29), 18567 (18), $18575(24), 18723$ (2), 18920 (20), $19442(28), 18958(29), 18966(26), 20009$ (3), 20280 (5), 20290 (24), 20399 (20), $20646(28), 20937(24), 21216(6), 22972(5), 22980(6), 23220$ (20), $23397(18), 23420(12), 23897(22), 23912(15), 23934$ (15), 24150(12), 24792(12), 24801 (3), 24886(5), 25382 (7), 25647 (4), 25675(30), 25676(29), 25746(7), 25903 (6), 26190 (8), 26192 (24), 26207 (12), 26296(12), 26308 (6), 26309 (24), 26321(18), 26351(14), 26714(21), 26756(27), $27072(22), 27104(20), 28102(7), 28416(2), 29247(15), 29297(23)$, 29320 (20), 30900 (5), 31028 (22), 31054 (2), 31146 (16), 33438 (6), 33699 (4), 33764 (20), 35700 (20), 37306 (23), 37913 (6), 37920 (4), 38111 (2), 39306(20), 39311 (22), 39731 (28), 39919(2), 40201 (23), 40244 (7), 40302 (2), 40236(12), 40432 (6), $40705(21), 41045(15), 41709(22), 41082(20)$, $41817(7), 41831$ (28), 41885 (7), 41887 (20), 41889 (10), 41920 (10), $41939(29), 41941$ (7), $42183(12), 42213(10), 42670(4), 43329(12), 43528(14)$, 43633 (21), 44536 (7), 44585 (15), 46057 (21), 47562 (6), 48874 (14), 48930 (21), 50341 (14), 50896 (15), 51680 (20), 51886 (19), 52832 (15), 54881 (20), 56153(21), 56160 (24), 56432(14), 58528(15), 59110 (15), 59791 (24), 64012(3), 67501 (2), 68718(6), 68833(4), 68850 (22), 68938(12). Hertel, P.F.B. 224 (2). Hertel, R. 159 (2), 198 (7), 282 (29), 474 (28). Imaguire, N. 752 (29), 1079 (5), 1165 (29), 1819 (22), 2211 (27), 2630 (29), 2694 (12), 2756 (12), 2792 (29), 2794 (12), 3019 (27), 3040 (6), 3513 (27). Isernhagen, I. 216 (28), 218 (22). Junior, L.H.S. 2 (24). Kaehler, M. 4 (20), 114 (24). Kawasaki, M.L. 924 (7), 925 (3), 926 (10). Kierski, M.T.: 215 (29). Kinupp, V.F. 294 (15), 353 (27). Klein, E.F. 1 (7). Koczicki, C. 60 (24), 88 (27), 97 (2), 98 (7). Kozera, C. 157 (2), 491 (2), 515 (12), 927 (6), 1410 (28), 1528 (2), 2922 (11). Krapovickas, A. 23150 (21). Krieger, L. 7541 (20), 8153 (22), 11008 (28), 11307 (12), 11330 (20). Kummrow, R. 62 (6), 227 (29), 333 (5), 358 (2), 398 (2), 432 (2), 454 (15), 461 (12), 549 (23), 897 (10), 1614 (12), 1718 (12), 1753 (12), 1863 (29), 2605 (27), $3136(15), 3220$ (15), 3372 (24), 3373 (12). Kuniyoshi, Y.S. $194(5), 2780$ (29), 4937 (12), 4948 (24), $5154(15), 5243$ (4), 5324 (28), 5374 (23), 5421 (7), 5524 (15), 5559 (28), 5703 (28), 5722 (4), 5749 (4), 5785 (2), 5855 (28). Labiak, P.H. 1958 (5). Lacerda, A. 124 (27), 214 (5), 271 (2). Landrum, L.R. 405 (20), 2429 (6), 2903 (22). Lange, R.B. 7 (24), 1065 (5), 1272 (2). Langohr, M.I. 43 (12). Laroca, S. 51 (13). Liebsch, D. 416 (22). Lima, A. 51 (6), 99 (5). Lima, I.P. 10 (6). Lima, J.M.: 309 (13). Lima, R.X. 16 (23), 22 (28), 31 (4), $116(23), 224$ (28), 250 (23), 375 (23). Lindeman, J.C. 31 (12), 121 (28), 239 (22), 310 (12), 481 (5), 887 (2), 1127 (2), 3075 (3), 3278 (12), 3475 (2), 3618 (6), 4602 (29), 5877 (22). Lobato, T. 9 (29). Longhi, S.J. 1548 (4). Maltozo, I.J. 433 (5). Marinero, F.E.C. 11 (7). Mattos, A. 10 (2). Mattos, J. 10689 (6), 13723 (5). Melges, E. 8 (13). Meyer, F.S. 190 (17), 210 (9), 211 (24), 223 (27), 224 (27), 225 (24), 249 (6), 250 (6), 251 (6), 252 (5), 253 (5), 254 (21), 256 (5), 258 (21), 259 (22), 260 (22), 261 (5), 262 (5), 287 (6), 288 (12), 289 (12), 290 (6), 291 (9), 308 (2), $316(15), 312$ (20), 350 (29), 425 (1), 449 (12), 450 (6), 529 (30), 533 (30), 534 (30), 321 (26), 322 (26), 323 (26), $324(26), 325$ (26), 337 (26), 527 (24), 590 (11), 753 (13), 843 (15), 844 (25), 845 (25), 846 (25), 847 (25), 848 (25). Moreira, E.A. 10 (12), 376 (10). Moro, R. S. 656 (20), 785 (20), 871 (15), 907 (12), 908 (12), 924 (12), 926 (15). Motta, J.T. 213 (6), 289 (5), 362 (24), 605 (8), 607 (8), 616 (7), 620 (2), 1071 (15), 1629 (4), 1630 (23). Moure, J.S. 967 (5). Neto, F. M. 62 (1). Nicolack, V. 88 (7), 91 (10). Oliveira, P.I. 208 (21), $298(7), 333$ (12), 561 (22), 692 (7), 866 (24). Paciornick, E.F. 337 (2). Pasdiora, A.L. 52 (7), 57 (7), 62 (24), 80 (7), 82 (8), 83 (24). Paula, M.F.R. 1 (9), 38 (24). Pedersen, T.M. 13760 (2), 15953 (5). Pereira, E. 5155 (29), 6060 (5), 6099 (12), 6891 (5), 7969 (6), 10581 (6). Pereira, M.L.: 123 (4), 318 (12), 348 (5). Poliquesi, C.B. 214 (7), 225 (7), 272 (12). Portes, M. C. 183 (24). Possete, R.F.S. 286 (12), 479 (5). Reginato, M. 26 (22), 94 (5), 217 (27), 402 (2), 403 (2), 660 (12), 656 (21). Resende, U. M. 1301 (9). Ribas, O.S.: 30 (28), 87 (2), 208 (12), 213 (21), 377 (28), 747 (24), 921 (7), $970(8), 1039(28), 1050(10), 1657(15), 1874(6), 2772(12), 3045(15), 3143(2), 3173(6), 3951(20), 3962(3), 4327(15), 4565(2), 5110(7), 5115(20)$, 5744 (24), 5785 (24), 6259 (2), 7040 (8), 7145 (5), 7491 (12). Ribeiro, D.C. 9 (6). Rizzi, G.I. 15 (2). Rizzini, C.T. 426 (6), 444 (12). Rocha, M.R.L. 18 (15), 21 (24), 75 (15). Roderjan, A.M. 7 (4). Roderjan, C.V. 377 (28), 392 (1), 668 (24), 756 (1), 767 (24), 773 (24), 831 (4), 1012 (1), 1019 (24), 1078 (24), 1143 (27), 1189 (1), 1287 (28), 1345 (7), 1442 (4), 1479 (6), 1564 (7). Rodrigues, W.A. 11310 (28), 11326 (4). Rosalino, M.E. 2 (27). Sá, K.L.R.V.: 74 (20), 113 (20), 191 (2), 224 (20), 308 (3), 414 (3), 499 (29), 500 (20). Saito, Y. 316 (5), 493 (6), 693 (22), 694 (4). Saldanha, J. 2 (2). Santos, E.P. 429 (12), 456 (29). Sauresig, D. 494 (2). Scheer, M. 19 (7), 221 (23), 286 (24), 324 (24), 493 (18). Schimmelpfeng, L.C. 35 (1). Schütz, A.L. 10 (20), 30 (12), 43 (21). Schwacke, C.A.W. 15 (22), 2610 (20), 2613 (6). Schwartsburd, P.B. 392 (12), 400 (7), 689 (29). Shirata, M.T. 191 (5), 238 (4). Silva, F.C. 645 (22), 729 (22). Silva, J.M. 90 (20), 100 (29), 292 (21), 466 (17), 497 (27), 564 (4), 718 (7), 773 (20), 776 (10), 1071 (29), 1440 (2), 1493 (7), 1616 (24), $1826(25), 1902$ (2), 2053 (7), 2243 (24), 2312 (10), 2613 (18), 2650 (7), 2651 (7), 3149 (7), 3181 (15), 3682 (7), 3810 (7), 3909 (7), $3936(24), 3943$ (7), 3965 (12), 4254 (10), 4646 (12), 4952 (7), 5113 (12), $5436(7), 5462$ (2), 5536 (10), 5559 (6). Silva, S. M.: 39 (4), 916 (22). Silveira, M. 7 (20). Smith, L.B. 14411 (7), 14488 (20), 14584 (20), 14801 (16), 14994 (5). Soares, A. 27 (21), 252 (7). Souza, W.S. 22 (4), 363 (22), 1084 (27). Sessegolo, G.C. 8 (21). Stellfeld, C. 302 (4), 1050 (12), 1053 (5), 1078 (2), 1079 (6), 1652 (29), 1654 (2), 1693 (27), 1801 (28), 3129 (29). Svolenski, A.C. 256 (7), 322 (7). Tardivo, R.C. 182 (12). Takahashi, E. 12 (7). Takeda, I.J.M. 456 (7), 498 (15). Tavares, F.: 1 (27). Tessmann, G. 275 (6), 974 (28), 2265 (12), 2589 (4), 2659 (23), 2792 (6), 2974 (29), 3015 (27), 3106 (2), 3627 (28), 3664 (5). Tiepolo, G. 35 (24), 235 (28). Tonetti, E. 15 (4). Tramujas, A.P. 251 (18). Varotto, R. 20 (7). Vicentini, A. 178 (29). Vieira, A.O.S. 285 (12), 321 (5), 12237 (12). Vieira, M.E.M. 17 (20). Lisingen, L. 128 (15), 141 (26), 142 (20). Zampieri, C. 121 (3). Ziller, S.R. 96 (28), 188 (15), 392 (12), 539 (23), 704 (28), 733 (23), 736 (28), 746 (23), 790 (22), 1184 (12), 1347 (2), 1471 (3), 1529 (12), 1569 (12), 1716 (12), 1957 (12). 